Araştırma Makalesi / Research Article

\title{
KÜRESEL VERGİ ŞEFFAFLIĞININ ARTIRILMASINDA ULUSLARARASI BİLGI PAYLAŞIMININ ROLÜ
}

\author{
Arş. Gör. Muhammet AKTUĞ* (D) \\ Karadeniz Teknik Üniversitesi, İ̈BF, Trabzon (maktug@ktu.edu.tr) \\ Prof. Dr. Ersan ÖZ \\ Pamukkale Üniversitesi, IİBF, Denizli (ersanoz@gmail.com)
}

\begin{abstract}
ÖZET
Küreselleşme sürecinde gümrük engellerinin azalması, teknolojik gelişmeler neticesinde ulaşım ve nakliye maliyetlerinin düşmesi sınır ötesi ticari faaliyetlerin geçmişle mukayese edilemeyecek şekilde artmasın sağlamıştır. Küreselleşme ile bireylerin ve firmaların mobilitesinin yükselmesi, vergi kaçırma ve vergiden kaçınma firsatlarını artırmıştır. Vergi cennetlerinin yaygınlaşması uluslararası vergi rekabetini tetiklemiş ve kamu gelirlerini tehdit eder hale gelmiştir. Mükelleflerin ülke sınırlarını kolaylıkla aşabildiği buna karşıllk vergi idarelerinin yetkilerinin ülke içine hapsolduğu bir ortamda küresel vergi şeffaflı̆̆ının sağlanması için en etkili çözüm yolu, vergi konularında idareler arası bilgi paylaşımının sağlam bir zemine oturtulmasıdır. Bu çalışmanın amacı küresel vergi şeffaflığının sağlanmasında vergi konularında uluslararası bilgi paylaşımının önemini ve bilgi paylaşımında gelinen son noktayı ortaya koymaktır.
\end{abstract}

Anahtar Kelimeler: Küreselleşme, Vergi Cennetleri, Vergi Rekabeti, Vergi Şeffaflığı, Uluslrarası Bilgi Paylaşımı.

\section{THE ROLE OF INTERNATIONAL EXCHANGE OF INFORMATION IN IMPROVING OF GLOBAL TAX TRANSPARENCY}

\begin{abstract}
In the globalization process, breaking down of custom barriers and decrease of transportation costs as a result of technological developments have enabled to cross-border commercial activities to be increased in comparison with the past. Globalization has enabled individuals and firms to achieve a high mobility, increasing the possibility of tax evasion and avoidance. In particular, the proliferation of tax havens and harmful preferential tax regimes has triggered international tax competition and threatened public revenues. In an environment where taxpayers can easily cross borders and the powers of tax administrations remain within the country, the most effective solution to ensure global tax transparency is to improve international exchange of information in tax matters. The aim of this study is to reveal the importance of international exchange of information in tax matters in ensuring global tax transparency.

Keywords: Globalization, Tax Havens, Tax Competition, Tax Transparency, International Exchange of Information.
\end{abstract}

\footnotetext{
* Sorumlu yazar.

www.ijmeb.org ISSN:2147-9208 E-ISSN:2147-9194

http://dx.doi.org/10.17130/ijmeb.902215

Başvuru Tarihi: 19.12.2019, Yayına Kabul Tarihi: 18.07.2020
} 


\section{Giriş}

Tarihi perspektiften bakıldığında, küreselleşmeyle birlikte ülke ekonomilerinin ciddi bir kimlik değişimine uğradıkları görülmektedir. Geçmişte, bir ülkenin belirli üretim alanlarında uzmanlaşması o ülkenin hammaddeye yakınlığı, coğrafi konumu, işgücü yeterliliği gibi faktörlere bağlı iken, küreselleşmeyle birlikte durum değişmeye başlamıştır. Çünkü hammaddesi yetersiz olan ülke, coğrafi konumuna bakmaksızın gerekli kaynakları temin edebilmekte, ihtiyaç duyulan kas gücünü uluslararası iş gücü hareketliliğinden faydalanarak kolaylıkla temin edebilmektedir.

Dünya giderek artan bir şekilde globalleşirken, ekonomik aktörlerin uluslararası iktisadi-ticari faaliyetleri de o ölçüde artmaktadır. Vergi mükelleflerinin sınır ötesine kolaylıkla geçebildiği, vergi idarelerinin yetkilerinin ise ülke sınırlarıyla kısıtlı kaldığı bir ortamda vergiden kaçınma ve vergi kaçırma girişimlerinin önlenebilmesi için tek yol uluslararası iş birliğinin geliştirilmesidir. Bu çerçevede, uluslararası iş birliği ve koordinasyonun sağlanması için çok uluslu organizasyonlara büyük görevler düşmektedir. Nitekim IMF, Avrupa Birliği ve OECD gibi milletlerarası kuruluşlar, küreselleşme olgusunun global ekonomi üzerindeki baskısının hissedilmeye başladığı andan itibaren bu yönde adımlar atmaya başlamışlardır.

Gerek anaakım devletlerin gerekse çok uluslu organizasyonların, küresel vergi şeffaflığının artırılması hususunda en önem verdikleri noktalardan biri, vergi konularında idareler arası bilgi paylaşımının artırılmasıdır. Vergi konularında uluslararası bilgi paylaşımı ülkeler arasındaki vergi antlaşmalarıyla gerçekleştirilmektedir. Diğer bir ifadeyle ülkeler arası bilgi paylaşımının hukuki temeli uluslararası sözleşmelerle oluşturulmaktadır. Buna göre iki ya da daha fazla ülkenin, akdedecekleri bir sözleşme ile vergi konularında karşılıklı iş birliği yapmasının önünde hiçbir engel bulunmamaktadır. Zaman içerisinde, ülkeler arasındaki koordinasyon probleminin önüne geçmek adına, bilgi paylaşımının hukuki zemini daha çok, uluslararası organizasyonlar tarafından oluşturulmaya başlamıştır. Fakat bu durum bilgi paylaşımının mutlaka çok uluslu bir organizasyon çatısı altında gerçekleştirilmesini mecbur kılmamaktadır. Çünkü çok uluslu organizasyonların amacı, vergi konularında yardımlaşmayı kendi uhdelerinde toplamak değil, her hal ve şartta işbirliğini artırmaktır. OECD, BM ve AB gibi milletlerarası kuruluşlar, vergisel konularda uluslararası bilgi paylaşımını artırmak adına çeşitli faaliyetlerde bulunmaktadırlar. Ancak bu çalışmada esas itibariyle OECD'nin yaptığı çalışmalara değinilmektedir.

$\mathrm{Bu}$ çalışmanın amacı küreselleşme sürecinde ortaya çıkan ve vergi şeffaflı̆̆ını tehdit eden unsurları irdeleyerek, şeffaflı̆̆ın artırılmasında uluslararası bilgi paylaşımın önemini ortaya çıkarmaktır. Çünkü vergi konularında idareler arası bilgi paylaşımının, vergi şeffaflığının sağlanmasında anahtar bir role sahip olduğu düşünülmektedir. Çalışma, üç bölümden oluşmaktadır. İlk olarak; vergi şeffaflığı ve vergi şeffaflığını ortadan kaldıran faktörlere yer verilmiştir. İkinci olarak; vergi konularında uluslararası bilgi paylaşımı, bilgi paylaşımına hukuki dayanak oluşturan ulusal ve uluslararası hukuki düzenlemeler, ağırlıklı olarak OECD'nin faaliyetleri çerçevesinde değerlendirilmiştir. Çalışmada OECD’nin faaliyetlerine ağırlık verilmesinin sebebi, bu kuruluşun vergi konularında bilgi paylaşımı alanında öncü bir görev üstlenmesidir. Bu bölümün devamında, bilgi paylaşım türleri ele alınmıştır. OECD’nin 2014 yılında Vergi Konularında Finansal Hesap Bilgilerinin Otomatik Paylaşımı Standardına geçmesi ile en yaygın bilgi paylaşım türü haline gelen otomatik bilgi 
paylaşımı diğer bilgi paylaşım türlerine göre daha detaylı olarak incelenmiştir. Son olarak ise Türkiye'nin uluslararası bilgi paylaşımında nerede olduğu ve bu kapsamda gerçekleştirdiği faaliyetler, ulusal ve uluslararası mevzuat çerçevesinde anlatılmıştır.

\section{Vergi Şeffaflı̆̆ı}

Geçmişten günümüze, finansal bilgilerin mahremiyeti konusunda köklü bir değişim yaşanmıştır. Geçmişte vatandaşların hangi bilgilerinin niçin gizli kalmaması gerektiği hususunda ikna görevi devlete ait iken, günümüzde vatandaşlar hangi bilgilerinin niçin saklı kalması gerektiği konusunda devleti ikna etmek zorundadırlar. Bugünkü hâkim görüş, insanların bankacılık ve diğer finansal işlemlerine ilişkin bilgilerin gizli kalması için hiçbir meşru sebep olmadığı yönündedir. Bu düşünce tarzı "bir yerde gizlilik varsa az uzağında bir dolandırıcılık vardır" veya "saklanacak bir şey yoksa korkulacak bir şey de yoktur" mantığına dayanmaktadır (Sharman, 2009:718). Bu doğrultuda şeffaflık anlayışında da değişmeler olmuştur. Geçmişte şeffaflık denildiğinde hükümetlerin halka karşı açık ve hesap verebilir konumda olmaları anlaşılmaktayken, sonrasında vatandaşların şeffaflığına yönelik, örneğin vergi şeffaflığı gibi, yeni kavramlar ortaya çıkmıştır. Bilhassa küreselleşmenin etkisiyle uluslararası ekonomik ilişkilerin girift hale gelmesi ve vergi kaçırma, vergiden kaçınma, kara para aklama, terörün finansmanı gibi faaliyetlerin kolaylaşması gerek hükümetleri gerekse milletlerarası kuruluşları karşı adımlar atmaya zorlamıştır. Netice itibariyle vatandaşlar (vergi mükellefleri), şeffaflık konusunda sadece hesap soran değil aynı zamanda hesap veren bir mevkie gelmişlerdir.

Vergi şeffaflığı, vergi mükellefi olan kişi ve kurumların devlete karşı şeffaf olmalarını ifade eder. Toplumda, genellikle varlıklı kişilerin ve büyük şirketlerin kanunların etrafından dolanarak vergi ödevlerini tam anlamılla yerine getirmedikleri (Alexander, 2013:548), peçeleme yapmak suretiyle vergilerini hakkıyla ödemedikleri, verginin özellikle tavana yayılamadığı şeklinde bir algı vardır. Vergiye ilişkin yükümlülüklerini yerine getirmekten kaçınan bu tür kişi ve kurumlar, sosyal sözleşme düşüncesine göre, bir nevi insan hakları ihlalinde bulunmuş olmaktadırlar (Stewart, 2018:3). Zira verginin, medeni bir toplumda yaşamanın bedeli olduğu düşünüldüğünde, vergi kaçıran veya vergiden kaçınan vatandaşların, bu görevi tam manasıyla yerine getirenlerin haklarını ihlal ettikleri gibi bir sonuç ortaya çıkmaktadır.

Modern devlet anlayışında kamu harcamalarının, dolayısıyla da bu harcamaları finanse etmek için ihtiyaç duyulan vergilerin çok önemli bir yeri vardır. Bir devletin neyi yapıp neyi yapamayacağını belirleyen temel faktör bu devletin ne kadar vergi toplayabildiğidir. Zira vergi olmadan, sürdürülebilir bir devlet idaresi oluşturmak imkânsızdır. Devlet, temel gelir kaynağı olan vergiyi doğru zamanda ve doğru miktarda toplayabilmek için mükelleflerin şahsi ve ailevi vaziyetleri ile iktisadi faaliyetleri hakkında bilgi sahibi olmak zorundadır. Vergisel bilgilerin şeffaflı̆̆ı/aleniliği konusunda devlet ile vergi mükellefleri arasında bir çıkar çatışması mevcuttur. Meseleye devlet açısından bakıldığında vergi, bir gelir kaynağı iken, mükellef açısından bakıldığında bir gelir kaybıdır. Devlet, mükellefler hakkında ne kadar detaylı bilgiye sahip olursa kamu alacağı olan vergi o denli güvence altına alınmış olur. Vergi idarelerinin mükellefler hakkında doğru bilgilere ulaşabilmesi vergi mevzuatının uygulanmasını kolaylaştırdığından, vergi-şeffaf çevrenin, sağ lıklı bir vergi sistemi içi şart olduğu söylenebilir.

Finlandiya, Norveç, Japonya ve diğer bazı ülkelerde mükelleflerin ödedikleri veya ödemedikleri vergilere ilişkin bilgilerin kamuoyuna açıklandığ büyük çoğunluğunda mükelleflerin vergi mahremiyeti hukuki teminat altına alınmıştır (Stewart, 
2018:17). Modern bir hukuk sistemine sahip her ülkenin vergi mevzuatında vatandaşlara ait vergisel bilgilerin güvenlik ve gizliliği ile ilgili hükümler yer almaktadır. Örneğin Türkiye'de Vergi Usul Kanunu'nun 362'nci maddesi “vergi mahremiyetinin ihlali” başlığını taşımakta ve bu maddeyi ihlal edenlerin 1 yıldan 3 yıla kadar hapis ve 5000 güne kadar adli para cezasıla cezalandırılacağı belirtilmektedir. Ancak Türkiye'de kamuoyunda “vergi yüzsüzleri” olarak bilinen ve belli bir miktarın üzerinde kesinleşmiş borcu (2019 yılı için 250 Bin Türk lirası) olduğu halde ödemeyenlerin listesi, Gelir İdaresi Başkanlığg tarafından her yıl ilan edilmektedir. Bunun yanında en çok vergi ödeyenlerin listesi de mükelleflerin onayını almak kaydıyla kamuoyuna açıklanmakta olup bu uygulamalar vergi mahremiyetinin ihlali kapsamında değerlendirilmemektedir.

Bugün gelinen noktada vergi şeffaflığını üç boyutta ele almak mümkündür: (1) Vergi mükelleflerinin kendi vergi idarelerine karşı şeffaflı̆̆ı; (2) Mükelleflere ait kâr, kazanç ve ödenen vergi miktarı gibi bilgilerin kamuoyuna açıklanması; (3) Vergiye ilişkin bilgilerin uluslararası şeffaflığı (Stewart, 2018:12). Bu çalışmada esas olarak, uluslararası vergi şeffaflığının sağlanmasına yönelik çalışmalar ele alınmaktadır.

\subsection{Vergi Şeffaflığını Ortadan Kaldıran Faktörler}

Küresel vergi şeffaflı̆̆ını tehdit eden zararlı vergi rekabeti, vergi cennetleri, transfer fiyatlandırması yoluyla örtülü kazanç dağıtımı, elektronik ticaretin yaygınlaşması ve sınır ötesi faaliyetlerin takibinin zorlaşması gibi unsurların tamamı farklı şeyler olsa da işin esası bakımından birbiriyle yakından ilgilidir. Dolayısıyla, vergi şeffaflı̆̆ $\breve{a r t ı r}_{1}$ mak isteniyorsa bu tür unsurlar, tek tek değil, bütüncül bir yaklaşımla ele alınmalıdır. Örneğin vergi cennetleri, vergi sistemlerini kaynak ülkelerin aleyhine olacak şekilde düzenleyen, dolayısıyla zararlı vergi rekabetinde bulunan ülkelerdir. Bireyler ve çok uluslu şirketler ise elektronik ticaret veya transfer fiyatlandırması yoluyla vergi avantajı elde ettiklerinden, rekabet ortamının hem öznesi hem de nesnesi konumundadırlar. Vergi cennetleri, diğer ülkelerin zararına olacak şekilde vergi oranlarını düşürüp kazanç elde etme peşindeyken, aynı şekilde bireyler ve firmalar da faaliyetlerini düşük vergi oranlarına sahip bölgelere kaydırıp, rakiplerine göre rekabet güçlerini artırma peşindedirler. Kısacası, vergi şeffaflığı konusunda olayın merkezinde "zararlı vergi rekabeti” kavramı bulunmaktadır. Gelinen noktada, zararlı vergi rekabeti global bir sorundur.

Ekonomilerin küreselleşmesi, sınır aşırı ticaret hacminin büyümesi, finansal işlemlerin ve şirketlerin uluslararası hareketliliğinin artması, mükelleflerin vergi kaçırma ve vergiden kaçınma imkanlarını da artırmıştır. Ülkelerin, mobilitesi yüksek gelir ve sermayeyi kendi sınırları içine çekip vergi tabanlarını genişletmek istemeleri uluslararası vergi rekabetini tetiklemiştir. Devletler, ülkelerini gelir ve sermaye için cazip kılmak adına, vergi oranlarını düşürmede birbirleriyle yarışa girmişlerdir. Bunun son örneği Amerika Birleşik Devletleri'nde kurumlar vergisi oranının indirilmesi olmuştur. ABD'de uzun süre \%35 olarak uygulanan federal kurumlar vergisi, ABD firmalarının uluslararası rekabet gücünü artırmak adına 2017 y1lında \%21'e indirilmiştir (US Congress, 2017:44).

Günümüzde devletler geçmişe oranla çok daha fazla gelir elde etmekle beraber küreselleşmenin ortaya çıkardığı bazı gelişmeler vergi şeffaflı̆̆ını ve dolayısıyla vergi sistemlerini tehdit etmeye başlamıştır. Vito Tanzi vergi sistemlerine zarar veren bu oluşumları "mali termitler" olarak nitelemektedir. Tanzi’ye göre doğadaki termitler nesneleri nasıl kemiriyorsa mali termitler de vergi sistemlerini öyle kemirmekte ve vergi kaybına neden 
olmaktadır. Tanzi, tespit edebildiği kadarıyla küreselleşme sürecinde sekiz adet mali termit ortaya çıktığını fakat bu sayının daha da fazla olabileceğini iddia etmektedir (Tanzi, 2000:4). Tanzi'nin mali termit olarak adlandırdığı ve vergi konularında şeffaflığı ortadan kaldırarak milli bütçeleri tehdit eden unsurlar şu şekildedir:

\section{a. Elektronik Ticaret ve Elektronik Ortamda Gerçekleştirilen İşlemler}

Elektronik ticaret hacmi internet kullanımın yaygınlaşmasına paralel olarak artış göstermeye devam etmektedir. Dünya genelindeki internet kullanan kişi sayısı 2014 yılında yaklaşık olarak 3 milyar iken bu rakam Haziran 2019 itibariyle 4,5 milyar seviyelerine ulaşmıştır (Internet World Stats, 2019). Buna paralel olarak 2014 yılında 1,3 trilyon dolar olan perakende e-ticaret hacmi 2019 yılında 3,53 trilyon dolara yükselmiştir (Statista). Teknolojik gelişmeler neticesinde internet erişiminde kullanılan araçların çeşitlenmesi dünya genelinde internet kullanımını artırdığı gibi e-ticaret hacmini de artırmıştır. Bunun yanında vergi idarelerinin, elektronik ortamda gerçekleştirilen ticari işlemleri gerektiği şekilde tespit ve takip edememesi vergi kaybına neden olmaktadır.

\section{b. Elektronik Para Kullanımı}

Tanzi'nin mali termit olarak nitelendirdiği ikinci gelişme, elektronik para (e-cash) kullanımının hızla yaygınlaşması ve reel para kullanımının yerini almaya başlamasıdır. Tanzi'nin bu tespiti 2000 yılı öncesinde yaptığ ve o dönemde blockchain teknolojisinin yaygınlaşmadığ ve bitcoin benzeri kripto para birimlerinin mevcut olmadığı düşünülürse bugün içinde bulunulan durumun vahameti daha iyi anlaşılabilir. Çünkü, Kasım 2019 itibariyle, en popüler 100 kripto para biriminin toplam piyasa değeri 222 milyar dolardan fazladır (CoinMarketCap, 2019). Bu rakam 2018 yılında 400 milyar dolar seviyesinin üzerine çıkarak zirveye ulaşmış ancak bazı ülkelerin kripto para birimlerine karşı tavır almaları neticesinde düşüşe geçmiştir. Fakat kripto para hacmi düşmüş rakamlarla bile oldukça yüksek seviyede bulunmakta ve kayıt dışı ekonomiyi kolaylaştırarak devletlerin vergi gelirlerini tehdit etmeye devam etmektedir.

\section{c. Şirket İci Ticaret}

Küreselleşmeye birlikte gümrük duvarlarının etkisini yitirmesi, ulaşım ve nakliyenin hem kolaylaşması hem de ucuzlaması çok uluslu şirketlerin yaygınlaşmasına neden olmuştur. Birden fazla ülkede faaliyette bulunan bu şirketler vergi avantajı elde etmek için şirket içi ticarette yani aynı kuruluşa ait fakat farklı ülkelerde bulunan şirketler arasındaki işlemlerde emsallere uygunluk ilkesini ihlal etmekte ve transfer fiyatlandırması denilen durum ortaya çıkmaktadır.

\section{d. Offshore Finans Merkezleri ve Vergi Cennetleri}

Vergi cennetleri mobilitesi en yüksek üretim faktörü olan sermayeyi kendi bölgelerine çekmek için oldukça agresif tercihli vergi rejimleri uygulamaktadırlar. Vergi cennetlerinde gerçekleştirilen finansal işlemlerin neredeyse tamamı paravandır. Yani olduğu iddia edilen işlemler aslında hiç gerçekleşmemektedir. Bu sebeple vergi cennetleri "sanal” merkezler olarak nitelendirilmektedir (Palan vd., 2010:21). Bu sanal merkezler kendi vatandaşları olmayan insanlar için finansal işlemleri kolaylaştırmaya yönelik kanuni düzenlemeler yapmakta ve uluslararası hukuktan doğan hükümranlık haklarını diğer ülkelerin zararına olacak şekilde kullanmaktadirlar. 
Vergi cenneti denilince insanların aklına vergi kaçırma, kara para aklama, zimmete geçirme vb. gibi olumsuz düşünceler gelmektedir. Bu sebeple vergi cenneti olarak nitelendirilen ülkelerin çoğu, kendilerine verilen bu sıfatı reddetmekte ve uyguladıkları politikaların olsa olsa tlımlı tercihli vergi rejimi olarak vasıflandırılabileceğini iddia etmektedirler (Palan vd., 2010:23). Elbette bu ülkelerin vergi cennetinden daha hafif bir sifat olan tercihli vergi rejimi ifadesini kullanmak istemeleri normaldir. Ancak tercihli vergi rejimi kavramı, vergi cennetlerinin fonksiyonlarını tam manasıyla yansitmaktan uzaktır.

Genel olarak vergi cennetlerinin amacı, uluslararası sermayeye, anaakım ülkelerin mevzuatından kaçış imkânı sağlamak ve buradan kazanç elde etmek şeklinde ifade edilmektedir. Ancak meseleye sadece bu açıdan bakmak problemi hafife almak olacaktır. Çünkü vergi cennetlerinin ilgisini çeken şey sadece sermaye değil, mobilitesi yüksek olan her türlü kıymettir. Vergi cennetlerinin uluslararası sermayeyi hedef alması da bu üretim faktörünün mobilitesinin yüksek olmasından kaynaklanmaktadır. Nitekim, teknolojik gelişmeler neticesinde mobilitesi yükselen her şey çok kısa süre içerisinde vergi cennetlerinin ilgi alanına girmektedir. Bilhassa internet, vergi cennetlerinin nakliye, kumarhane ve pornografi gibi mobil işletime uygun alanlardaki faaliyetlerini kolaylaştırmaktadır (Palan vd., 2010:23).

\section{e. Türevler ve Koruma Fonlart}

Türevler ve koruma fonları gibi yeni finansal araçların ortaya çıkışı ve bu araçlar kullanılarak zayıf mevzuata sahip bölgelere kaydırılan iktisadi kıymetler vergi gelirlerini azaltan önemli unsurlardan biridir. Koruma fonlarının çoğu bilhassa hukuki düzenlemelerin zayıf olduğu off-shore merkezlerden idare edilmektedir. Hatta sanayileşmiş ülkelerde yer alan koruma fonlarının bile yeteri kadar düzenlemeye tabi kılındığını söylemek zordur.

\section{f. Ülkelerin Finansal Sermayeyi Gerektiği Gibi Vergilendirememesi veya Vergilendirmek Istememesi}

Küreselleşmeyle birlikte kazandıkları yüksek hareket kabiliyeti (mobilite) sermaye ve nitelikli iş gücünün üretim faktörleri içindeki önemini daha da artırmıştır. Günümüzde devletler sermaye ve nitelikli emek üzerinden alınan vergileri düşürmekte ve buradan kaynaklanan gelir kaybını mobilitesi düşük kıymetler üzerindeki vergileri artırarak telafi etme yoluna gitmektedirler. Kalifiye iş gücü ve sermayenin hareket serbestisi nedeniyle sahip olduğu vergi avantajı, gelir dağılımını mobilitesi düşük üretim faktörlerinin aleyhine olacak şekilde bozmaktadır.

Tek Pazar'ın kurulmasıyla beraber, AB üyesi ülkelerdeki işletmelerin büyük pazarlara ulaşma imkânı yakalaması rekabeti artırmış, rekabetin artması ise fiyatları düşürerek refahın yükselmesini sağlamıştır. Gerek şahısların gerekse işletmelerin Tek Pazar içinde serbestçe hareket edip, faaliyetlerini kendileri açısından en avantajlı sektör ve ülkelere taşımaları, iktisadi etkinlik açısından olumlu bir gelişme olarak görülse de zaman içerisinde ülkelerin vergi mevzuatlarındaki farklılıklardan kaynaklı problemler ortaya çıkmaya başlamıştır. Avrupa Birliği her ne kadar Tek Pazar olsa da 28 üye ülkenin her birinin farklı vergi mevzuatına sahip olduğu göz önüne alındığında ortaya çıkan problemler daha iyi anlaşılabilir. Tek Pazar'ın sağladığı rekabetçi ortam içerisinde, vergi tabanlarını genişletmek isteyen Birlik üyeleri vergi rekabetine girişmişler ve vergi oranlarını diğer üyelerin aleyhine olacak şekilde düşürme yoluna gitmişlerdir. Bu sebeple kalifiye iş gücü ve sermaye gibi mobilitesi yüksek iktisadi kıymetler 
üzerindeki vergi oranları 1990'lardan günümüze sürekli düşme eğilimindedir (European Commission, 2015:4).

Tek Pazar içinde vergi şeffaflığının artırılması için Avrupa Komisyonu'nun, atılmasını önerdiği adımların başında vergi meselelerinde idareler arası bilgi paylaşımının yaygınlaştırılması gelmektedir. Avrupa Komisyonu, vergi şeffaflığının artırılması için sadece $A B$ üyelerinin çabalarının kâfi gelmeyeceğini, Birlik üyesi olmayan devletlerle de koordinasyon içinde çalışılması lazım geldiğini ve başta BEPS eylem planı olmak üzere OECD tarafından yapılan düzenlemelere bağlı hareket edilmesi gerektiğini vurgulamaktadır (European Commission, 2015:12).

\section{g. Ülke Dışı Faaliyetlerin Artması}

Vergi mükelleflerinin, iktisadi faaliyetleri ikamet ülkeleri dışına taşıyıp vergi avantajı elde etmeye çalışmaları anaakım devletlerin gelirlerini tehdit eden önemli etkenlerden biri olarak değerlendirilmektedir. Burada çoğu zaman uluslararası düzeyde çalışma kabiliyetine sahip donanımlı profesyoneller devreye girmekte, mükelleflerin vergi kaçırma ve vergiden kaçınma girişimlerini organize etmektedirler. Bilhassa vergisel amaçlı bilgi değişiminin mümkün olmadığı durumlarda yurt dışı ticari faaliyetler aracılığıyla kayba uğratılan vergi miktarı çok yüksek miktarlara ulaşabilmektedir. Bu tür faaliyetler sadece, tespit ve takip bakımından görece zayıf durumdaki gelişmekte olan ülkeleri değil gerek mevzuat gerekse de teknolojik bakımdan en üst seviyedeki ülkeleri bile tehdit etmektedir. Örneğin Richard Murphy tarafından hazırlanan bir rapora göre, Avrupa Birliği içerisinde yıllık vergi kaçağı miktarının yaklaşık 850 milyar avro, mükelleflerin vergiden kaçınmaları suretiyle meydana gelen yıllık vergi kaybının ise 150 milyar avro civarında olduğu tahmin edilmekte ve ikisi bir araya geldiğinde 1 trilyon avroyu aşan bir miktar karşımıza çıkmaktadır. AB üyesi ülkeler içinde yıllık vergi kaçağının en yüksek olduğu ülkenin yaklaşık 180 milyar avro ile İtalya, vergi kaçağının kamu harcamalarına oranının en yüksek olduğu ülkenin ise \%28 ile Estonya olduğu ifade edilmektedir. Raporda ayrıca, vergi kayıp kaçağının bireysel olarak ülkelerin değil, bütün Birliğin problemi olduğuna ve AB içindeki yıllık vergi kaçağının Birliğin sağlık hizmetleri bütçesinden daha fazla olduğuna dikkat çekilmektedir (Murphy, 2012:2).

\section{h. Ülke Dışından Alışveriş}

Tanzi'nin mali termit olarak nitelendirdiği diğer bir durum, yurt dışına seyahat eden mükelleflerin kendi ülkelerinde yüksek oranda vergilendirilen ürünleri düşük vergili bölgelerden temin etmeleridir. Özellikle 20. Yüzyıl'ın ikinci yarısından itibaren bireylerin seyahat edebilme imkân ve özgürlüklerinin artması ülke dışı alışverişi artırmıştır. Bu çerçevede bireyler kendi ülkelerinde yüksek vergi uygulanan, bilhassa yükte hafif pahada ağır diye tabir edilen lüks tüketim mallarını düşük vergili bölgelerden temin etme yoluna gitmektedirler. Bireylerin alışverişlerini yurt dışına taşımaları birçok ülkenin vergi sisteminde ciddi değişiklikler yapılmasına neden olmuştur. Küreselleşmenin etkilerinin iyice hissedilmeye başlandığı 1980’lerden günümüze lüks tüketim malları üzerindeki vergiler sürekli düşme eğilimindedir.

Avrupa Birliği'nde, dolaylı vergiler alanındaki zararlı rekabetin önüne geçebilmek için katma değer vergisi ve bazı ürünler (alkol ve tütün) üzerinden alınan özel tüketim vergilerinde uyumlaştırma yapılmış olmakla beraber, dolaysız vergiler alanındaki vergi rekabeti artarak devam etmektedir. Avrupa Komisyonu, dolaysız vergiler alanındaki zararlı 
rekabetin önüne geçmek ve bilhassa kurum gelirlerinin AB içerisinde etkin ve adil bir şekilde vergilendirilmesini sağlamak için bazı adımlar atılmasını öngörmektedir. Komisyon'un bu amacın gerçekleştirilmesine yönelik olarak ortaya koyduğu beş ana hedeften biri de AB içerisinde vergi şeffaflı̆̆ının sağlanmasıdır.

\section{Vergi Konularında Uluslararası Bilgi Paylaşımı}

Elde edilen gelirin nerede vergilendirileceğiyle ilgili, geniş kabul gören iki yaklaşım mevcuttur. Bunlardan biri gelirin, doğduğu yerde (kaynak ülkede) vergilendirilmesini öngören "kaynak ilkesi" iken diğeri, her nerede elde edilmiş olursa olsun gelirin, ikamet edilen ülkede vergilendirilmesi gerektiğini öne süren "ikametgâh ilkesi”dir. Çoğu ülke, vergi sisteminde bu ilkelerin ikisine de yer vermekte; mukim olanlar için ikametgâh esasını, mukim olmayanlar için ise kaynak esasını kabul edip vergilendirme hakkını en yüksek seviyede tutmaya çalışmaktadır. Aynı mükellef hakkında, bir ülke ikametgâh ilkesini uygulamak isterken, diğer bir ülkenin kaynak ilkesini uygulamak istemesi durumunda ise çifte vergilendirme problemi ortaya çıkmaktadır. Çifte vergilendirme problemi mükellefler üzerinde aşırı yük oluşturup saptırıcı etkilere sebep olabileceğinden, ülkeler genellikle imzaladıkları çifte vergilendirmeyi önleme antlaşmaları ile bu sorunu çözmeye çalışmaktadırlar. Uygulamada, çifte vergilendirmenin engellenmesine yönelik olarak indirim, istisna ve mahsup gibi yöntemler kullanılmaktadır. İstisna yönteminde mukim ülke, kendi vatandaşının yurtdısında elde ettiği geliri tamamen vergi dışı bırakıp vergilendirme hakkını kaynak ülkesine terk etmekte iken, mahsup ve indirim yöntemlerinde yurt dışında elde edilen gelirin tamamı değil bir kısmı vergi dışı bırakılmaktadır. Fakat her hal ve şartta mukim ülkelerin, sınır ötesi faaliyetlerde bulunan vatandaşlarının ödeyeceği vergi miktarını tam olarak hesaplayabilmek için öncelikle bu faaliyetler hakkında bilgi sahibi olmaları gerekmektedir. Bu noktada, vergi konularında idareler arası karşılıklı bilgi paylaşımı, vergi yükünün dengeli ve adil dağılımı için büyük önem arz etmektedir. Kayıt dışı faaliyetlere sığınak sağlamayı geçim kapısı haline getirmiş vergi cenneti ülkeler bir tarafa bırakılırsa, vatandaşlarının sınır ötesi faaliyetlerden elde ettikleri geliri vergilendirmek isteyen her devlet, diğer devletlerle iş birliğine gitmek ve koordinasyon içinde bilgi paylaşımında bulunmak zorundadır.

Ülkelerin çifte vergilendirmeyi önleme antlaşması imzaladıkları durumlarda karşılıklı bilgi paylaşımı daha da önemli hale gelmektedir. Zira ülkelerin mükellefler hakkındaki bilgi eksikliği çifte vergilendirmeme (double non-taxation) durumuna sebep olabilmektedir. Örneğin, iki ülkenin çifte vergilendirmeyi önlemek için istisna yönteminde mutabakata vardıklarını ve vergilendirme hakkını mukim ülkeye bıraktıklarını varsayalım. Buna göre kaynak ülke, mukim ülke vatandaşlarını vergilendirme hakkından vazgeçerken mukim ülke, vatandaşlarının kaynak ülkedeki faaliyetleri hakkında doğru bilgiye ulaşamazsa söz konusu kişileri gerektiği gibi vergilendiremeyebilir. Dolayısıyla bu kişiler iki ülkede de vergi ödemediklerinden, vergilendirmede adalet bozulmuş olur.

Geçmişte, uluslararası ticaretin gümrük tarifeleri ve kotalarla kısıt altına alındığı, sermaye ve işgücü seyyaliyetinin düşük olduğu dönemlerde farklı ülkelerin vergi idareleri arasında iş birliği ve bilgi paylaşımına ancak istisnaî durumlarda ihtiyaç duyulmaktaydı. Fakat küreselleşme sürecinde uluslararası ticaretin büyük oranda serbestleşmesi, ulaşım ve nakliye imkânlarının artması ve maliyetlerin düşmesi, teknolojik ilerlemeler ile internetin birey ve firmalara sağladığı avantajlar sayesinde sınır-ötesi işlemlerin çok büyük boyutlara ulaşması bu 
durumu değiştirmiştir. Geçmişte, milli sınırlar içerisinde vatandaşlarının faaliyetleri hakkında ihtiyaç duydukları her türlü bilgiye kolayca erişebilen mukim ülke vergi idareleri, sınır ötesi faaliyetler hakkında bilgi edinmek için kaynak ülke vergi idarelerine muhtaç hale gelmişlerdir.

Uluslararası seviyede idareler arası iş birliği ve bilgi paylaşımının olmadığı bir ortamda vergi kaçırmak çok kolaydır. Örneğin faiz geliri üzerindeki yüksek vergiden kurtulmak isteyen bir mükellefin, kendi ülkesiyle bilgi paylaşımında bulunmayan düşük vergili ülkelerden birinde banka hesabı açması yeterlidir. Bugün gelinen noktada yüksek gelir grubundaki kişi ve kurumlara anaakım devletlerin vergi mevzuatından kaçış imkânı tanıyan ve vergi cenneti olarak nitelendirilen çok sayıda ülke mevcuttur. Zuchman, hane halklarına ait global küresel servetin yaklaşık \%8'inin vergi cennetlerinde tutulduğunu ve bu servetin dörtte üçünün kayıt dışı olduğunu öne sürmektedir. Ayrıca Zuchman, yaptığı çalışmada, daha büyük bir tehlikeye dikkat çekmekte; Avrupa'daki sermayenin önce kayıt dışı yollarla vergi cennetlerine akıtıldığını, sonrasında ise tekrar Avrupa'daki kişi ve kurumlara bu kaynaklar üzerinden kredi kullandırıldığgnı ve kimin borçlu kimin alacaklı olduğunun bilinemediği tespitinde bulunmaktadır (Zuchman, 2013:1360).

Vergisel konularda uluslararası iş birliği ve bilgi paylaşımının olmaması durumunda vergi kayıp ve kaçağında meydana gelecek artış, işin ahlaki boyutundaki tehlikenin yanında mali ve iktisadi tehditler de barındırmaktadır. Sermayenin düşük vergili bölgelere kaçması nedeniyle anaakım devletlerin vergi gelirlerinde ciddi bir azalma meydana gelirken, bu durum vergi kaçıranların kamu hizmetlerine gerektiği gibi katılmamaları anlamına geldiğinden, gelir dağılımında adaleti de bozmaktadır. Ayrıca vergi ödemeyenlerin vergi ödeyenlere göre bir maliyet avantajı elde edecek olması toplumun vergi ahlakını olumsuz etkilemektedir.

\subsection{Bilgi Paylaşımının Hukuki Dayanağı}

Vergi konularında idareler arası karşılıklı bilgi paylaşımının hukukî dayanağının biri ulusal diğeri uluslararası iki boyutu bulunmaktadır. Ulusal boyut, mükelleflerin paylaşıma konu olacak bilgilerinin toplanması, depolanması ve diğer ülkelere gönderilmesi için idareye yetki veren iç hukuk düzenlemelerini ifade etmektedir. Örneğin Türkiye' de, vergi konularında idareler arası bilgi paylaşımına ilişkin iç hukuk düzenlemeleri, büyük ölçüde, Vergi Usul Kanunu'nun 148-152'nci maddeleri ile 152/A maddesinde yer almaktadır. Bilgi paylaşımının uluslararası boyutu ise karşılıklı bilgi paylaşımında bulunacak iki veya daha fazla ülkenin bu işlemi aralarında akdettikleri uluslararası bir sözleşme ile hukuki zemine oturtmalarını ifade etmektedir.

Her ülke uluslararası hukuktan doğan hakkına dayanarak diğer ülkelerle anlaşma imzalamak serbestisine sahiptir. Ülkeler bu haklarını, diğer ülkelerle ferdî anlaşma yapmak şeklinde kullanabilecekleri gibi, uluslararası bir organizasyon çatısı altında hazırlanan her türlü anlaşma ve sözleşmeye taraf olmak şeklinde de kullanabilirler. Haddizatında, uluslararası sistemin anarşik yapısı dikkate alındığında meseleyi milletler arası anlaşmalardan başka bir yöntemle halletmenin imkânı da yoktur. Çünkü uluslararası hukuk esasında bir sözleşme hukukudur.

OECD’nin bilgi paylaşımı alanındaki çalışmalarının hukuki iki temel dayanağı bulunmaktadır. Bunlar; OECD Model Vergi Anlaşması (Model Tax Convention) ve Vergi Meselelerine Yönelik Karşılıklı İdari Yardımlaşma Anlaşması (CoE/OECD The Multilateral 
Convention on Mutul Administrative Assistance in Tax Matters)'dır. AB ülkeleri ise birliğin bilgi paylaşımı ile ilgili çıkardığı direktifleri esas alan iç hukuk düzenlemeleriyle aralarındaki koordinasyonu sağlamaya çalışmaktadır.

Vergi konularında bilgi paylaşımının uluslararası boyutunun hukuki temeli sözleşme/ anlaşma hukuku ile oluşturulmaktadır. Bilgi paylaşımına ilişkin kavram ve şartların belirlenmesinde genellikle özel çalışma sözleşmesi (special working agreement), mutabakat bildirisi (memorandum of understanding, $M O U$ ) veya benzeri hukuki araçlar kullanılmaktadır. Örneğin iki ülke arasında imzalanan tipik bir mutabakat bildirisi ile paylaşılacak bilgilerin türü, bilgilerin gönderim ve alımına ilişkin prosedürler, bilgilerin hangi formatta gönderileceği vb. gibi detaylar tespit edilmektedir. OECD, vergi idarelerinin bilgi paylaşımında esas alabilecekleri, sekiz maddelik bir mutabakat bildirisi modeli hazırlamıştır. Modelin birinci maddesinde mutabakat bildirisinin (MOU) konusu, ikinci maddede hangi bilgilerin paylaşılacağ1, üçüncü, dördüncü, beşinci ve altıncı maddelerde bilgilerin hangi hüküm ve şartlara göre gönderileceğine ilişkin detaylar, yedinci ve sekizinci maddelerde ise mutabakat bildirisinin hangi isimle anılacağı ve ne zaman yürürlüğe gireceğine ilişkin düzenlemeler yer almaktadır (OECD, 2002b).

\subsection{Uluslararası Bilgi Paylaşımının Gelişim Süreci}

Uluslararası seviyede mütekabiliyet esası altında bilgi paylaşımında bulunabilmek için çeşitli yöntemler kullanılmaktadır. Bunlardan ilki ve en yaygın olarak kullanılanı, çifte vergilendirmeyi önleme anlaşmaları içerisine yerleştirilen hükümlerle vergiye ilişkin bilgilerin paylaşılması şeklindedir. Çünkü çifte vergilendirme probleminin doğası gereği, meselenin çözüme kavuşturulabilmesi için idareler arası bilgi paylaşımı zaruridir. Devam eden süreçte vergi kayıp ve kaçağının artması çok uluslu kuruluşların, idareler arası bilgi paylaşımı konusuna ağırlık vermelerine sebep olmuş ve doğrudan bilgi paylaşımının hukuki ve teknik altyapısını oluşturan anlaşmalar ortaya çıkmıştır.

\subsection{1. Çifte Vergilendirmeyi Önleme Anlaşmaları Çerçevesinde Bilgi Paylaşımı}

OECD, Avrupa Birliği, Avrupa Konseyi, Milletler Cemiyeti (League of Nations, 19201946) ve Birleşmiş Milletler gibi çok uluslu organizasyonların, vergi konularında uluslararası bilgi paylaşımını konu alan çok sayıda çalışması mevcuttur. Birinci Dünya Savaşı sonrasında kurulup, İkinci Dünya Savaşı akabinde dağılan Milletler Cemiyeti'nin, bilgi paylaşımına yönelik çalışmaları zamanın şartları icabı, daha çok uluslararası çifte vergilendirmenin önlenmesine yönelik olmuştur. Günümüzde $\mathrm{OECD}, \mathrm{BM}$ ve AB tarafından yapılan çalışmalar ise çifte vergilendirmeyi de göz önünde bulundurmakla beraber, ağırlıklı olarak vergi kayıp ve kaçağının engellenmesi amacını taşımaktadır.

Resmi olarak kayıtlara geçen ilk bilgi paylaşımı 1843 yılında Belçika ile Fransa arasında imzalanan çifte vergilendirmeyi önleme antlaşması ile gerçekleştirilmiştir. Bu antlaşmanın esas amacı çifte vergilendirmenin önlenmesi olmakla beraber iki ülke vatandaşlarının vergi kaçırmasını önlemek amacıyla gayri menkuller ile kayıt ve tescile tabi işlemelere ilişkin bilgilerin karşılıklı paylaşımına da yer verilmiştir. Buna benzer fakat daha kapsamlı bir girişim 1920'li yıllarda Milletler Cemiyeti tarafından başlatılmıştır. 1920 Yılında Brüksel'de düzenlenen Uluslararası Finans Konferansı'nda çifte vergilendirmenin yurtdışı yatırımların önünde engel oluşturduğu ve Milletler Cemiyeti'nin bu meseleyle ilgilenmesi gerektiği gündeme gelmiştir 
(League of Nations, 1920:237). Cemiyet bu konuyla ilgili olarak Geçici Finans Komitesi'ni görevlendirmiştir. Finans Komitesi de çifte vergilendirmenin ekonomik etkilerini ve olumsuz sonuçlarını araştırmak, bunların önüne geçmek için ne gibi tedbirler alınabileceğini tespit etmek üzere Prof. Bruins (Commercial University), Prof. Seligman (Columbia University), Prof. Einaudi (Turin University) ve Sir Josiah Stamp (London University) 'a davette bulunmuştur. Zamanın dört ünlü iktisatçısından oluşan bu heyet tarafından hazırlanan rapor 1923 yılında yayınlanmıştır (Coates, 1924:99). Geçici Finans Komitesi uluslararası çifte vergilendirme ve uluslararası vergi kaçakçılığı meselesini incelemek üzere 1922 yılında Belçika, Çekoslovakya, Fransa, İtalya, Hollanda, İsviçre ve İngiltere'den yedi üst düzey vergi yetkilisine davette bulunmuştur. 1925 yılında yedi ülke temsilcisinden oluşan bu grup Arjantin, Almanya, Japonya, Polonya ve Venezüella'yı kapsayacak şekilde genişlemiştir. Çifte Vergilendirme ve Vergi Kaçakçılığı Teknik Uzmanlar Komitesi olarak anılan gruba 1927 yılında ABD de dahil olmuştur (UNPAN). Söz konusu komite, 1923-1927 yılları arasında yaptığı çalışmalar ve düzenlediği oturumlar neticesinde genel bir rapor yayınlamıştır. Raporda dört ayrı model vergi anlaşması sunulmuştur. Bu model vergi sözleşmelerinden biri de Vergi Meselelerinde Çift Taraflı İdari Yardımlaşma Anlaşması (Bilateral Convention on Administrative Assistance in Matters of Taxation) adını taşımakta ve doğrudan doğruya uluslararası bilgi paylaşımını konu almaktadır (Dean, 2008:639-642). Daha sonra Milletler Cemiyeti, Meksika (1943) ve Londra (1946) tasarıları olarak bilinen iki çalışma daha yapmıştır. Hem Meksika hem de Londra tasarıları çifte vergilendirmeyi önleme ve karşılıklı idari yardım anlaşması modelleri üzerine yoğunlaşmıştır. Bir müddet sonra da bu iki farklı tasarı tek bir model anlaşma altında birleştirilmiştir (Dean, 2008:644).

Milletler Cemiyeti 2. Dünya Savaşı akabinde çalışmalarına son verince uluslararası vergilendirmeye yönelik faaliyetler OECD’nnin öncüsü olan Ảvrupa Ekonomik İşbirliği Teşkilatı (OEEC) tarafından yürütülmeye başlanmıştır. OEEC 1955 yılında çifte vergilendirme ile ilgili tavsiye kararları yayınlamış, 1958-1961 yılları arasında ise Çifte Vergilendirmenin Önlenmesi (The Elimination of Double Taxation) başlı̆̆ 1 altında dört adet rapor hazırlamıştır. Bir müddet sonra OEEC, bugünkü OECD (Ekonomik İşbirliği ve Kalkınma Teşkilatı) 'ye dönüşmüş ve 1963 yılında Çifte Vergilendirme Anlaşması Tasarısı, OECD tarafından kabul edilmiştir. OECD bu tarihten günümüze dek çifte vergilendirmenin önlenmesine yönelik birçok çalışma yapmış ve yapmaya devam etmektedir. Fakat 1963 tarihli Çifte Vergilendirme Anlaşması Tasarısı uluslararası bilgi paylaşımı yönünden büyük öneme sahiptir. Zira devam eden süreçte bu tasarının 26'ncı maddesi vergilendirmeye müteallik uluslararası bilgi paylaşımında en önemli kaynaklardan biri haline gelmiştir (OECD, 1963:56). 1963 tarihli bu modelin öngördüğü bilgi paylaşımı türü “talep üzerine bilgi paylaşımı” olup, modelin kapsamı gelir ve sermaye üzerinden alınan vergilerle sınırlandırılmıştır. OECD 1977 yılında 1963 Model Vergi Anlaşmasını revize ederek yeni bir Model Vergi Anlaşması ortaya koymuştur. 1977 modelinde, 1963 modeline büyük oranda sadık kalınmakla beraber, ufak bazı değişiklikler yapılmıştır (OECD, 2017a:10).

\subsubsection{OECD Model Vergi Anlaşması ve TIEA Modeli Altında Bilgi Paylaşımı}

OECD Model Vergi Anlaşması’nda genel olarak, vergilendirme hakları ikamet ülkesi lehine düzenlenmiştir. Haliyle, çoğunluğu gelişmekte olan ülke kategorisinde olan kaynak ülkeleri bu duruma tepki göstermiştir. Zira tasarruf-yatırım açığı bulunan kaynak ülkeleri bir taraftan ekonomilerine yabancı sermaye çekmeye çalışırken diğer taraftan kendi sınırları 
içerisinde gerçekleşen uluslararası faaliyetlerden yeteri kadar vergi geliri elde edememenin sıkıntısı içine düşmüşlerdir. OECD Model Vergi Anlaşması'nı kendi lehlerine bulmayan gelişmekte olan ülkelerin endişelerini gidermek adına, Birleşmiş Milletler tarafından yeni bir model vergi anlaşması oluşturulmuştur. Birleşmiş Milletler Model Vergi Anlaşması, büyük oranda OECD modeliyle benzerlik göstermekle beraber, kaynak ülkelerinin vergilendirme yetkilerini genişletici hükümler içermektedir. Fakat meseleye bilgi paylaşımı açısından bakıldığında BM modeli ile OECD modeli arasından önemli bir fark bulunmamaktadır.

OECD 2000 yılında, BM ise 2001 yılında model vergi anlaşmalarında bilgi paylaşımının kapsamını genişleten tadilatlar yapmıştır. Yapılan tadilatların özü, bilgi paylaşımının sadece model vergi anlaşmasında düzenlenen vergilerle sınırlı kalmaması, modele aykırı düşmemek kaydıyla ülkelerin iç hukuk sistemlerindeki tüm vergileri kapsayacak şekilde genişletilmesi şeklinde ifade edilebilir. Buna göre, model vergi sözleşmesinde sadece gelir ve sermaye üzerinden alınan vergiler yer almasına rağmen, yapılan değişiklikle modelde yer almasa bile KDV, ÖTV, Veraset ve İntikal Vergisi gibi vergilerin de bilgi paylaşımına konu olması sağlanmiştır.

OECD zararlı vergi rekabetiyle mücadele etmek için, Zararlı Vergi Uygulamaları Forumu (Forum on Harmful Tax Practices, FHTP)'nu kurmuş ve 1998 yılında Zararlı Vergi Rekabeti: Ortaya Çıkan Global Bir Sorun (Harmful Tax Competition: An Emerging Global Issue) adlı raporunu yayınlamıştır. OECD bu raporda, vergi rekabetine neden olan faktörleri ele alarak, zararlı tercihli vergi rejimi ve vergi cenneti gibi oluşumların özelliklerini açıklamıştır. Raporda, zararlı vergi uygulamalarıyla mücadelede, idareler arası iş birliği ve bilgi paylaşımının artırılarak vergi şeffaflığının sağlanmasının önemi vurgulanmıştır.

OECD, 2000 yılında yayınladı̆̆ı Vergi Alanında Küresel İsbirliğine Doğru: Zararlı Vergi Uygulamalarının Belirlenmesi ve Ortadan Kaldırılmasında Kat Edilen Mesafe (Towards Global Tax Co-operation: Progress in Identifying and Eliminating Harmful Tax Practices) adıyla bir rapor daha yayınlamış ve 1998 yılında yayınladığ sağlamayan tercihli vergi rejimleri ile vergi cenneti ülkeleri tek tek ifşa etmiştir (OECD, 2000a:12-17).

OECD, 1998 yılında yayınladı ğı zararlı vergi rekabetiyle ilgili raporla birlikte, dikkatini büyük ölçüde vergi şeffaflı̆̆ının artırılması ve bu amaçla idareler arası bilgi paylaşımının işlevsel hale getirilmesine çevirmiştir. Nitekim 2000 yılında Vergi Meselelerinde Banka Bilgilerine Erişimin Geliştirilmesi (Improving Access to Bank Information for Tax Purposes) adıyla bir rapor daha yayınlanmış ve raporda vergiyle ilgili konularda, banka bilgilerine erişimin kolaylaştırılmasına yönelik önerilere yer verilmiştir (OECD, 2000b).

Vergisel amaçlı bilgi paylaşımında uluslararası iş birliğini geliştirmek için, OECD tarafından 2000 yılında Vergi Meselelerinde Bilgi Paylaşımı ve Şeffaflı Küresel Forumu (Global Forum on Transparency and Exchange of Information for Tax Purposes) ${ }^{1}$ kurulmuştur. Küresel Forum idareler arası bilgi paylaşımında kullanılmak üzere, Vergi Konularında Bilgi Paylaşım Anlaşması Modeli (Model Agreement on Exchange of Information in Tax Matters, TIEA) hazırlamış ve 2002 yılında yayınlamıştır. Bilgi Paylaşım Antlaşması Modeli'nin amacı, 1998 raporunda açıklanan zararlı vergi uygulamalarıyla mücadelede bilgi paylaşımını etkin

1 Not: Çalışmanın devamında bu forumdan "Küresel Forum”, şeklinde bahsedilecektir. 
kılmak bakımından, hukuki bir araç oluşturulması şeklinde açıklanmıştır (OECD, 2002:1). Bu anlaşma modeli, aralarında daha önce vergiye yönelik bir sözleşme mevcut olmayan ülkelerin karşılıklı bilgi paylaşımında bulunmalarına hukuki zemin hazırlaması açısından önemlidir.

2005 yılında OECD Model Vergi Anlaşması'nın 26'ncı maddesinde tadilat yapılarak bu madde, TIEA Modeli ile uyumlu hale getirilmiştir. Model Vergi Anlaşması'nın bilgi paylaşımına yer verilen 26'ncı maddesinin kapsamı, modelde yer almayan vergi türlerine ilişkin bilgileri de (modele aykırı olmamak koşuluyla) kapsayacak şekilde genişletilmiştir. OECD Model Vergi Anlaşması'nın 26'ncı maddesinde paylaşım konusu olacak bilgileri açıklarken “Sözleşmeci devletlerin yetkili makamları bu Antlaşma'nın hükümlerinin yerine getirilmesinde ........ gerekli bilgileri paylaşmalıdırlar" ibaresinde geçen "gerekli" ibaresi, "ilgili olduğu öngörülen" şeklinde değiştirilerek, ricacı devletlerin talep edebilecekleri bilginin kapsamı genişletilmiş olmaktadır. Bu değişiklik neticesinde, bilgi paylaşımına konu olacak bilgilerin mutlaka vergiyle alakalı olmasına gerek olmadı̆̆ı, vergiyi alakadar edebileceği düşünülen her türlü bilginin talep edilebileceği şeklinde bir yorum yapılabilirse de OECD söz konusu değişikliğin böyle bir amaç taşımadığını ifade etmiştir. Ancak 26'ncı maddenin yine OECD tarafından yapılan şerhinde, söz konusu değişikliğin, hem "mümkün olan en geniş şekilde bilgi paylaşımında bulunulması" hem de "alakasız konuların, paylaşım kapsamına alınmasının önüne geçilmesi” amaçlarını taşıdığına yer verilmesi bir tezat gibi gözükmektedir.

2012 yılında, OECD Model Vergi Anlaşması'nın 26'ncı maddesi bir kez daha düzenlenerek "ilgili olduğu öngörülen" ifadesinin anlamı belirginleştirilmeye çalışılmıştır. Buna göre ricacı devletin diğer sözleşmeci devletlerden bilgi talebinde bulunabilmesi için, söz konusu bilginin bir şekilde vergiyle alakalı olduğunun düşünülmesi yeterli görülmüş, nihai aşamada bu bilginin vergiyle alakasının olmadığının anlaşılmasının önem arz etmediğine dikkat çekilmiştir. Burada, kendisinden bilgi talep edilen devletin, ricacı devletin talebine hüsnü niyetle yaklaşıp, istenilen bilginin vergiyle alakalı olduğuna inanmaktan başka yapabileceği bir şey kalmamaktadır. Ancak talep edilen bilginin, vergi maksatlı olmadığından kesin olarak emin olunursa, ricacı devletin talebi reddedilebilmektedir (OECD, 2012a). OECD Model Vergi Sözleşmesi'nde bilgi paylaşımının kapsamı belirlenirken "(vergiyle) ilgili olduğu öngörülen" şeklinde müphem ve genişletici yoruma imkân tanıyacak bir ifadeye yer verilmesinin mükellef hakları açısından sakıncalı olduğu söylenebilir.

2012 yılında yapılan düzenleme ile OECD Model Vergi Anlaşması’nın, paylaşılan bilgilerin mahremiyetini konu alan, 26'ncı maddesinin 2'nci fikrasına, " $a k i t$ bir devletten alınan bilgi, bu âkit devletin rıza göstermesi ve her iki devletin hukuki mevzuatına aykırı olmamak kaydı şartıyla, vergi dışı maksatlarla kullanılabilir" şeklinde bir cümle ilave edilmiştir. Bu düzenleme ile, diğer devletlerden bilgi paylaşımı talebinde bulunan devletler, aldıkları bilgileri vergi dışı konularda da kullanma imkanına kavuşmuşlardır.

\subsubsection{CoE/OECD Vergi Konularında Karşılıklı İdari Yardımlaşma Anlaşması Çerçevesinde Bilgi Paylaşımı}

Uluslararası vergi kaçırma ve vergiden kaçınma faaliyetleriyle mücadele etmek için OECD ve Avrupa Konseyi tarafından 1988 yılında Vergi Konularında Karşılıklı İdari Yardımlaşma Anlaşması (CoE/OECD, Convention on Mutual Administrative Assistance in Tax Matters) imzalanmıştır. İdari Yardımlaşma Anlaşması, vergi alanında her türlü iş birliğini 
bünyesinde barındıran, karşılıklı ve kapsamı en geniş hukuki araç olma özelliğini taşımaktadır. OECD Model Vergi Anlaşması'nda muhtemel bilgi paylaşımı türlerine 26'ncı maddenin yorum kısmında sadece değinilmekle iktifa edilmiş olmasına rağmen, İdari Yardımlaşma Anlaşması'nda bilgi paylaşım türlerinin her birine ayrı maddeler halinde detaylı olarak yer vermiştir. İdari Yardımlaşma Anlaşması'nın 5'inci maddesi istek üzerine bilgi paylaşımını, 6'ncı maddesi otomatik bilgi paylaşımını, 7'nci maddesi ise spontane bilgi paylaşımını konu almaktadir.

İdari Yardımlaşma Anlaşması, iki taraflı bilgi paylaşım anlaşmalarına göre çok daha kapsamlı hükümler ihtiva etmektedir. Çünkü Anlaşma kapsamında, sadece bilgi paylaşımına değil, eş zamanlı vergi incelemesi (madde 8), yurtdışında vergi incelemesi (madde 9), tahsilatta yardımlaşma (madde 11) ve alacağın korunması (madde 12) gibi konulara da yer verilmiş̧tir.

İdari Yardımlaşma Anlaşması'nın 27'nci maddesinin 1'inci fıkrasında “Bu Sözleşme'nin sağladı ğ yardımlaşma imkanları, ilgililer arasında mevcut olan veya gelecekte yapılacak olan uluslararası anlaşmalar ile sair düzenlemelerde veya vergi konularında işbirliğine ilişkin diğer araçlarda yer alan yardımlaşma imkanlarını kısıtlamaz ve bunlar tarafindan kısıtlanmaz" hükmüne yer verilmiştir. Bu ifadelerden anlaşılacağı üzere İdari Yardımlaşma Anlaşmasının amacı, vergi konularında uluslararası yardımlaşmayı CoE/OECD’nin tekeline almak veya sadece belirli standartlara bağlamak değil, vergi şeffaflı̆̆ını artırmak için her türlü işbirliğini teşvik etmektir.

İdari Yardımlaşma Anlaşması'nda, bilgi paylaşımından doğan masrafların nasıl karşılanacağı da belirtilmektedir. Buna göre ilgili devletler, masrafların taksiminde kendi aralarında bir usul tespit etmekte serbesttirler. Ancak iki devlet bu konuda herhangi bir mutabakata varmamış ise olağan masraflar "talepte bulunulan devlet" tarafından, olağanüstü masraflar ise "yardım talebinde bulunan” devlet tarafından karşılanacaktır.

2010 yılında imzalanıp 2011'de yürürlüğe giren bir protokol ile İdari Yardımlaşma Anlaşması tadil edilerek bazı maddelerde değişiklikler yapılmıştır. 2010 Protokol'ünde, 25 Ocak 1988 tarihli İdari Yardımlaşma Sözleşmesi ile vergisel konularda bilgi paylaşımı konusunda uluslararası seviyede kabul gören standartlara ulaşılmasına rağmen takip eden süreçte uluslararası standartlarda değişmelerin olduğu ve idari yardımlaşmaya dahil olmak isteyen, iş birliğine açık yeni çevrelerin oluştuğuna dikkat çekilerek, yapılan düzenlemelerin gerekçesi ortaya koyulmuştur (OECD, 2010:1).

2010 Protokolü geniş çaplı değişiklikler içermemekle beraber 4, 18 ve 22'nci maddelerde yapılan düzenlemeler bilgi paylaşımı bakımından bilhassa önem arz etmektedir. Buna göre; 4'üncü maddenin 1988 versiyonunda yer alan "verginin tarh ve tahsili ve de vergi alacaklarının tazmin ve tenfiziyle"2 ilgili olduğu öngörülen bilgilerin taraflarca paylaşılmasını gerektiren hüküm, 2010 Protokolü'nde tarafların "iç vergi mevzuatlarının yürütülmesi ve uygulanmasıyla" ilgili olduğu öngörülen bilgilerin paylaşılmasını gerektirecek şekilde değiştirilerek, bilgi paylaşımının kapsamı genişletilmiştir. Yapılan bu değişiklik ile İdari Yardımlaşma Sözleşmesi, OECD Model Vergi Sözleşmesi'nin 26'ncı maddesi ile uyumlu hale getirilmiştir.

2 Not: Burada "vergi alacaklarının tazmin ve tenfizi" ibaresinden kasıt, mükelleflerin alacaklarının, yani mükelleflerden fazla ya da yanlış olarak alınmış vergilerin iadesi ve buna ilişkin işlemlerin yapılmasıdır. 
İdari Yardımlaşma Sözleşmesi'nin, hakkında bilgi talebinde bulunulan kişinin doğru tespit edilebilmesi için ricacı devlet tarafından sağlanacak bilgilerle ilgili 18'inci maddesinde de küçük bir değişiklik yapılarak ricacı devletin sağlayacağı bilgilerin kapsamı genişletilmiştir. Buna göre; 18'inci maddenin 1'inci fıkrasının b bendinde yer alan "hakkında bilgi talebinde bulunulan kişinin ad, adresi ve bu kişinin kimliğinin tespitine yarayacak diğer hususlar" ifadesindeki " $v e$ " ibaresi "veya" olarak değiştirilerek, bilgi talebinde bulunulacak devlete gönderilen bilgilerin kapsamı genişletilmiştir. Böylece, hakkında bilgi talebinde bulunulan mükellefin kimliğinin doğru bir şekilde belirlenmesi için, bilgi talebinde bulunan devletin talepte bulunduğu devletlere mükellef hakkında daha fazla bilgi vermesine imkân sağlanmıştır. İdari Yardımlaşma Sözleşmesi'nin 18'inci maddesinin kendisinden bilgi talep edilen devletin değil, bilgi talebinde bulunan devletin sağlayacağ maddedeki değişikliğin önemsiz olduğu düşünülebilir. Zira, burada bilgi talebinde bulunan devletin, hakkında bilgi talep ettiği mükellef ile ilgili bilgileri karşı tarafa vermesinde kendisi açısından bir sakınca yoktur. Çünkü söz konusu mükellefin kimliğinin doğru tespit edilip, gerekli bilgilerinin kendilerine ulaştırılması mukim ülkelerin lehinedir. Ancak bu durum mükellef hakları açısından bazı sakıncalar barındırmaktadır. Sözleşme metninde böyle bir maddenin yer alması ve daha sonra bu maddenin kapsamının genişletilmesi bilgi talebinde bulunan veya kendisinden bilgi talep edilen devletler için önemli olmasa da mükellef hakları bakımından büyük öneme sahiptir. Çünkü bu madde âkit devletlere, mükelleflere ait şahsi bilgileri elde etmek ve karşı tarafa göndermek için hukuki bir dayanak sağlamaktadır.

2010 Protokolü neticesinde İdari Yardımlaşma Anlaşması’nın, paylaşıma konu olan bilgilerin gizlilik ve güvenliği ile ilgili 22'nci maddesinin 1 ve 2'nci fıkralarında da bazı düzenlemeler yapılmıştır. Buna göre paylaşılan bilgilerin mahremiyetinin sağlanması için, bilgiyi alan tarafın söz konusu bilgilere, kendi iç mevzuatında kişisel verilerin korunmasında gösterilen özenle hareket etmesi gereği vurgulanmıştır. Fakat kişisel verilerin gizliliğiyle ilgili mevzuatta, bilgiyi alan tarafın bilgiyi sağlayan taraftan daha zayıf olabileceği tehlikesi dikkate alınarak, bilgiyi alan tarafın, kendi mevzuatını uygularken bilgiyi sağlayan tarafın iç mevzuatıyla uyumlu hareket etmesi gerektiğine de dikkat çekilmiştir.

Yine 22'nci maddenin 1988 versiyonunda, paylaşıma konu bilgilerin kimler tarafından nasıl kullanılacağı hususunda "Bu bilgiler sadece o Tarafin verginin tarh, tahsil ve cebri icrast veya kovuşturması ya da bu alandaki itirazlara bakmakla yetkili kişi ya da makamlarına (mahkemeler ile idari makamlar veya denetim kurumları dahil) gösterilebilir. Bahsi geçen bilgileri sadece yukarıda belirtilen kişi ya da makamlar yalnızca bu amaçlara yönelik olarak kullanabilir. Bu kişiler söz konusu bilgileri l'inci fikra hükümleriyle bağlı kalmaksızın, bilgiyi sağlayan tarafın önceden izni alınmak kaydı şartıyla, bu vergilerle ilgili mahkeme duruşmalarında ve adli kararların alınması esnasında açılayabilirler. Fakat iki veya daha fazla taraf, karşılıklı anlaşma yoluna gitmek suretiyle önceden izin alma şartından feragat edebilirler" ifadeleri yer almaktaydı. Ancak 2010 Protokolü ile, paylaşıma esas bilgilerin yetkili kişilerce mahkemelerde veya adli kararların alınması esnasında açıklanabilmesi için gerekli olan bilgiyi sağlayan taraftan önceden izin alma şartı kaldırılmıştır. Bu sayede taraflar, elde ettikleri bilgileri karşı tarafın onayını almadan vergiyle ilgili mahkeme duruşmalarında ve adli kararlarda gösterebilme hakkına kavuşmuşlardır. İdari Yardımlaşma Anlaşması'nın hem 1988 hem de 2010 versiyonunda “l'inci fikra hükümleriyle bağlı kalmaksızın” ibaresinin yer alması, 22. maddenin 1'inci fıkrasında kişisel verilerin korunmasına yapılan vurgunun, 
aynı maddenin 2'nci fıkrasında hükümsüz bırakıldığı görülmektedir. Bu hükümsüzlük belirli şartların varlığına (sadece vergiyle ilgili dava duruşmaları ve adli kararlarda gösterilebilme gibi) bağlı olsa bile mükellef hakları açısından tezat oluşturmaktadır. Zira 22'nci maddenin 1'inci fıkrasında mükelleflere verilen mahremiyet hakkı, mezkûr maddenin 2'nci fıkrasında geri alınmış olmaktadır.

\subsubsection{OECD BEPS Eylem Planı’nın Bilgi Paylaşımı Açısından Değerlendirilmesi}

OECD, küreselleşme sürecinde ortaya çıkan zararlı vergi uygulamalarıyla mücadele etmek için 15 adet BEPS eylem planı geliştirmiştir. 2013 yılında Saint Petersburg'da gerçekleştirilen zirvede, G20 ülkeleri tarafından onaylanan bu Plan'daki 5. ve 13. Eylemler idareler arası bilgi paylaşımıyla yakından ilgilidir. OECD' ye göre “özün önceliği ilkesi ve şeffaflı dikkate alınarak zararlı vergi uygulamaları ile mücadele edilmesi” şeklindeki 5. Eylemin tam anlamıyla icra edilmesi için, mükelleflerle yapılan peşin fiyatlandırma anlaşmaları ${ }^{3}$ (advance pricing arrangements, APA) ve mükelleflere verilen özelgelerin mukim ülke vergi idareleriyle paylaşılması gerekmektedir. Bu sayede idareler arası iş birliği ve koordinasyonun artırılarak, tercihli vergi rejimi uygulamalarının önüne geçilmesi planlanmaktadır (OECD/G20, 2015a:52). 13. Eylem Planı ise çok uluslu şirketlerin, kârın dağıtımı ve matrah aşındırması faaliyetlerinin önüne geçmek için, transfer fiyatlandırması belgelendirme kurallarının revize edilip geliştirilmesini ifade etmektedir. Bu çerçevede 13. Eylem Planı çok uluslu şirketlere yönelik Ana Dosya (Master File), Lokal Dosya (Lokal File) ve Ülke Bazında Raporlama (country-by-country, CbC, Report)'dan oluşan üç katmanlı bir yükümlülük getirmektedir. Ana Dosya'da çok uluslu şirketin, küresel ölçekte gerçekleştirdiği faaliyetler, transfer fiyatlandırmasına ilişkin genel şirket politikası ile ticari faaliyetlerin ve gelirlerin küresel ölçekte nasıl dağıtıldığıyla ilgili bilgiler yer almaktadır. Lokal Dosya ‘da çok uluslu şirketlere ait, dünyanın çeşitli yerlerinde konumlanmış lokal kuruluşlar arasındaki işlemler yer almaktadır. Burada Lokal Dosya, Ana Dosyayı tamamlayıcı bir niteliğe sahiptir. Ülke Bazında Raporlama (CbC Report) ise çok uluslu şirketlerin, hangi ülkede ne kadar kazanç elde ettikleri, ne kadar vergi ödedikleri, vergi sonrası kazançları, sermayeleri, varlıkları, çalıştırdıkları eleman sayısı gibi hususların ilgili ülkelere bildirilmesini gerektirmektedir (OECD/G20, 2015b:14-16). Çok uluslu şirketlere BEPS eylem planı çerçevesinde getirilen bildirim ödevleri, idareler arası paylaşıma tabi olacak bilgilerin elde edilmesi bakımından önemlidir.

2014 y1lında OECD ve G20 ülkelerinin öncülüğünde “Vergi Konularında Finansal Hesap Bilgilerinin Otomatik Paylaşımı Standardı” kabul edilerek uluslararası bilgi paylaşımı konusunda yeni bir sisteme geçilmiştir. Yeni standart ve bu çerçevede yer alan Ortak Raporlama Standardı çalışmanın devamında detaylı olarak ele alınacaktır.

\subsection{Bilgi Paylaşım Türleri}

Geleneksel olarak, bilgi paylaşımının üç türü bulunmaktadır. Bunlar; talep üzerine bilgi paylaşımı (exchange of information on request, EOIR), otomatik bilgi paylaşımı (automatic exchange of information, AEOI) ve spontane bilgi paylaşımı (spontaneous exchange of information) 'dır. OECD bilgi paylaşımının bu üç türüyle de ilgili çalışmalar yapmaktadır.

3 Not: Peşin Fiyatlandırma Anlaşması, ilişkili kişiler ile yapılan mal ve hizmet alım satımlarındaki transfer fiyatının tespit edilmesinde belirli bir süre için uygulanacak yöntemin, mükellefin talebi üzerine mükellef ile idare arasında gerçekleştirilecek bir anlaşma ile belirlenmesidir. Böyle bir fiyatın tespit edilmesi, mükellefin bu fiyat üzerinden gerçekleştirdiği işlemlerde, transfer fiyatlandırması suretiyle örtülü kazanç dağıtımı suçlamasıyla karşı karşıya kalmaması bakımından önemlidir. 


\subsubsection{Talep Üzerine Bilgi Paylaşımı}

İstek/talep üzerine bilgi paylaşımı (exchange of information on request, EIOR), idareler arası bilgi paylaşımında kullanılan en geleneksel ve en yaygın yöntemdir. Vergi konularında istek üzerine bilgi paylaşımı, aralarında sözleşme bulunan âkit devletlerden birinin yetkili makamının, diğer âkit devletlerin yetkili makamlarından belirli bir durum hakkında bilgi talep etmesidir.

OECD Model Vergi Sözleşmesi'nin 26'ncı maddesi ve CoE/OECD Vergi Konularında Karşılıklı İdari Yardım Sözleşmesi'nin 5'inci maddesinde istek üzerine bilgi paylaşımına yer verilmiştir. Model Vergi Sözleşmesi'nin 26'ncı maddesinde bilgi paylaşım türleri açıkça tanımlanmamış, bilgi paylaşım türlerine maddenin yorumunda değinilmiştir. Buna karşın İdari Yardımlaşma Anlaşması'nın 5'inci maddesi doğrudan, talep üzerine bilgi paylaşımını konu almaktadır. 5'inci maddenin 1'inci fikrası hükmünce; "Kendisinden bilgi talebinde bulunulan devlet, başvuruda bulunan devlete 4'üncü maddede belirtilen kişsi ve işlemelerle ilgili her türlü bilgiyi sağlayacaktır". Ayrıca aynı maddenin 2'nci fıkrası hükmünce, "Kendisinden bilgi talep edilen devletin kayttlarındaki bilgi, ricacı devletin talebini karşılamakta yeterli değil ise, bu devlet, ricacı devletin talep ettiği bilgiyi temin etmek için gereken tüm önlemleri alacaktır".

Özetlemek gerekirse, istek üzerine bilgi paylaşımında öncelikle bir devletin diğer bir devletten bilgi talebinde bulunması gerekmektedir. Daha sonra başvuruda bulunulan devlet, söz konusu talebi değerlendirmeye tabi tutup, istenilen bilgi kendisinde var ise bunu karşı tarafa iletmekte, yok ise bu bilgiyi sağlamak için gerekli tedbirleri almaktadır.

\subsubsection{Spontane Bilgi Paylaşımı}

Spontane bilgi paylaşımında, âkit devletlerden birinin diğer âkit devletlerden herhangi bir bilgi talebinde bulunmasına gerek yoktur. Bir âkit devlet, kendi vergi mevzuatına ilişkin uygulamaların normal seyri esnasında diğer âkit devlet ya da devletleri ilgilendireceğini düşündüğü bir bilgiyle karşılaşırsa, herhangi bir talep beklemeden söz konusu bilgiyi diğer tarafa iletmektedir. Paylaşıma konu olan bilgi genellikle, mükelleflerin, bilginin gönderileceği ülkedeki vergi yükümlülükleri ile ilgilidir. Örneğin bilgi paylaşımına ilişkin bir sözleşmeye taraf olan iki ülkeden biri, kendi ülkesindeki standart bir vergi denetimi esnasında, bir mükellefin diğer ülkedeki vergi yükünü etkileyecek bir bilgiye ulaştığında, bu bilgiyi karşı tarafa iletmektedir.

CoE/OECD Vergi Konularında Karşılıklı İdari Yardımlaşma Sözleşmesi'nin 7'nci maddesi spontane bilgi paylaşımı ile ilgilidir. Buna göre, bazı durumların varlığı halinde, âkit devletlerin, diğer âkit devletlerin talebini beklemeksizin bilgi paylaşımında bulunmaları istenmiştir. 7'nci maddenin l'inci fikrasının a, b, c, d ve e bentleri hükmünce, aşağıdaki şartların varlı̆̆ı halinde Taraflardan her biri, sahip olduğu bilgileri önceden bir talep olmaksızın diğer Tarafa gönderecektir:

- Bir Taraf, diğer Taraf 'ın vergi kaybına uğrayabileceğini düşünebilecek nedenlere sahipse;

- Vergiye tabi bir kişsi, bir Taraf'ta diğer Taraf'taki vergi yükümlülüğ̈n̈ü etkileyebilecek bir vergi indirimi ya da istisna elde etmekteyse;

- Bir Tarafta vergiye tabi olan bir mükellef ile diğer Tarafta vergiye tabi olan bir mükellef arasındaki iş anlaşması, bir veya daha fazla ülke aracılığıyla Taraflardan birinde, diğgerinde veya her ikisinde vergi tasarrufu elde edecek şekilde idame ettiriliyorsa; 
- Bir Taraf, kazancın teşebbüs grupları arasındaki sanal transferlerle dağıtımı sonucunda vergi tasarrufu meydana gelebilece ğini düşünecek nedenlere sahipse;

- BirTaraftandiğer Tarafagönderilen bilgi,bilginin gönderildiği tarafta vergimükellefiyetinin doğmasına sebep olacak bilgilerin elde edilmesini să̆layacak ise.

Ayrıca 7'nci maddenin 2'nci fıkrası hükmüne göre, “Taraflardan her biri, 1'inci fikrada tarif edilen bilgilerin diğer Tarafa ulaştırılması için gerekli tedbirleri almak ve prosedürleri uygulamakla yükümlüdür".

\subsubsection{Otomatik Bilgi Paylaşımı}

Otomatik bilgi paylaşımı; mükelleflerin temettü, faiz, maaş, emekli aylığı vb. gibi farklı gelir kategorilerine ait bilgilerinin, periyodik ve sistematik olarak, kaynak ülkeden mukimülkeye aktarılmasıdır (bkz.: Ateş, 2015). Otomatik paylaşıma konu olan bilgiler, kaynak ülkenin rutin olarak kayıt altına aldı ̆̆ ikamet değişiklikleri, gayrimenkullerin elden çıkarılması vb. gibi faydalı bilgileri kapsayacak şekilde genişletilebilmektedir. Düzenli bir vergi sistemine sahip her ülkede, mükelleflere ait bu tür bilgiler finansal kurumların, işverenlerin veya bizzat mükelleflerin bildirimlerinden elde edilmekte ve arşivlenmektedir (OECD, 2012b:7). Otomatik bilgi paylaşımı durumunda yapılması gereken, kaynak ülkelerin, sahip oldukları bilgileri mukim ülkelere bildirmesi, dolayısıyla mukim ülkelerin de kendi vatandaşlarının yurtdışındaki faaliyetleri konusunda sağlıklı bilgiye ulaşıp, mükelleflerin vergi mevzuatını delmeye yönelik olası girişimlerinin peşinen önüne geçebilmesidir.

Talep üzerine bilgi paylaşımı konusunda, prosedüre bağlı gecikmeler ve ülkelerin zaman zaman siyasi nedenlerle bilgi paylaşımını kesmeleri vb. gibi olumsuzluklar otomatik bilgi paylaşımına daha çok ağırlık verilmesine sebep olmuştur. 2014 yılında OECD tarafından Finansal Hesap Bilgilerinin Otomatik Paylaşımı Standardı (Standart for Automatic Exchange of Financial Account Information in Tax Matter) kabul edilerek, vergi konularında otomatik bilgi paylaşımı yeni bir çerçeveye oturtulmuştur. Otomatik paylaşıma konu olacak bilgilerin toplanıp, raporlanması ve bunların idareler arası paylaşımına imkân veren prosedür ise yine 2014 yılında kabul edilen Ortak Raporlama Standardı (Common Reporting Standardı) ile belirlenmiştir.

2014 yılından sonra, otomatik bilgi paylaşımı diğer bilgi paylaşımı türlerine göre daha çok tercih edilmeye başlanmıştır. Otomatik bilgi paylaşımı 2015 yılına kadar, OECD Model Vergi Anlaşması'nın 26’ncı maddesi ile Vergi Konularında Karşılıklı İdari Yardımlaşma Anlaşmasının 6'ncı maddesi baz alınarak yapılmaktaydı. 2002 yılında kabul edilen TIEA Modeli ise istek üzerine bilgi paylaşımı (IEOR) esasına dayanmakta, spontane ve otomatik bilgi paylaşımı türleri model kapsamında yer almamaktaydı. Bu eksikliği gidermek adına, OECD Mali İşler Komitesi tarafından 2015 Yılı'nda, TIEA altında otomatik ve spontane bilgi paylaşımına da imkân tanınması maksadıyla bir protokol kabul edilmiştir (OECD, 2015). Karşılıklı İdari Yardımlaşma Anlaşması ve OECD Model Vergi Anlaşması'nda otomatik bilgi paylaşımına kapsamlı olarak yer verilmiş olmasına rağmen, bazı durumlarda TIEA Modeli 'ne ihtiyaç duyulması, söz konusu Protokol'ün yapılmasına neden olmuştur. İdari Yardımlaşma Anlaşması ve OECD Model Vergi Anlaşması, aralarında daha önce vergi anlaşması imzalamış ülkelere yönelik iken TIEA Model'inde böyle bir zorunluluk yoktur. Yani, İdari Yardımlaşma 
Anlaşması ve Model Vergi Anlaşması'na taraf olmayan iki ülke, TIEA Modeli ile kolayca bilgi paylaşımında bulunabilmektedir. Dolayısıyla, 2015 Protokol'ü ile otomatik ve spontane bilgi paylaşımının TIEA Modeli kapsamına alınması, diğer sözleşmelere taraf olmayan devletler açısından büyük öneme sahiptir.

\subsubsection{Otomatik Bilgi Paylaşımı ve Ortak Raporlama Standardı (CRS)}

Vergi idarelerinin finansal kurumlardan, mükellefler hakkında bilgi edinmelerini ve bu bilgilerin diğer ülkelerin vergi idareleriyle otomatik olarak paylaşımını sağlamak üzere OECD tarafından 2014 yılında, Ortak Raporlama Standardı (Common Reporting Standard, CRS) adıyla bir sistem geliştirilmiştir. Ortak Raporlama Standardı doğrudan doğruya otomatik bilgi paylaşımına yönelik olarak geliştirilmiş bir sitemdir. Ortak Raporlama Standardı'nın oluşturulmasıyla, idareler arası paylaşıma konu olacak finansal hesap bilgileri, bildirimde bulunacak finansal kurumlar, sistem kapsaminda yer alacak mükellefler ve hesap türleri ile finansal kurumların takip edecekleri ortak prosedürler belirlenmiştir. OECD'nin böyle bir standart geliştirmesinde G20 ülkelerinin talepleri etkili olmuştur. CRS, dört kısımdan oluşmaktadır (OECD, 2017b):

- Model Yetkili Makam Anlaşması (Model Competent Authority Agreement, CAA); CRS kapsamında elde edilen bilgilerin otomatik paylaşımına uluslararası meşruiyet kazandırmak için oluşturulmuş bir anlaşma modelidir. Otomatik bilgi paylaşımında bulunacak ülkeler Yetkili Makam Anlaşması'nı imzalayarak söz konusu faaliyetlere hukuki bir zemin hazırlamış olmaktadırlar.

- Ortak Raporlama Standardı; paylaşıma konu olacak bilgilerin raporlanması ve bu çerçevede takip edilecek ortak prosedürleri içerir.

- CAA ve CRS hükümleri hakkındaki İzahatlar; CAA ve CRS hükümlerinin yorumlarına yer verilen ve idareler arası uygulamada tutarlılı̆̆g sağlamak üzere getirilen açıklamalardır.

- CRS XML Şema Kullanıc Kılavuzu (CRS XML Schema User Guide); CRS kapsamında elde edilen bilgilerin elektronik ortamda ve standart bir şekilde transferine imkân tantyan bir şemadır. Bu tür bilgi transferlerinde genellikle XML (extensible markup language genişletilebilir işaretleme dili) ${ }^{4}$ kullanilmaktadır.

\subsubsection{Otomatik Bilgi Paylaşımı Sürecinin İşleyişi}

OECD, otomatik bilgi paylaşımının sekiz aşamadan oluşan bir süreç içerisinde gerçekleştirilmesini öngörmektedir. Buna göre bir vergi mükellefine ödeme yapan kişi ya da kurum bu mükellefe ait bilgileri kayıt altına alır. Ödeme yapan kişi veya kurum, ödeme yaptı̆̆ı mükellefe ilişkin bilgileri mükelleften isteyebileceği gibi, bazı durumlarda bu bilgiler, ödeme yapan kişi ya da kurum tarafından bizzat üretilebilir. Ödeme yapan kişi ya da kurumlar, ödeme yaptıkları gayri mukim mükelleflere ait kimlik bilgilerini ve bunlara yapılan ödemeleri, kaynak ülkesinin mevzuatı uyarınca vergi idarelerine bildirir. Ödeme yapan kişi veya kurumlardan gelen bilgiler, gayri mukim mükelleflerin ikamet ettikleri ülkelere göre gruplandırılır (OECD, 2012b:9-10). Örneğin Fransa' da ikamet eden mükelleflerin bir dosyada, Almanya' da ikamet edenlerin başka bir dosyada toplanması vb. gibi.

4 Not: XML, internet üzerinden veri alışverişinde bulunan farklı kuruluşların standart hareket etmesini sağlayan bir işaretleme dilidir. 
Kaynak ülkesinde toplanan tüm bilgiler şifrelendikten sonra toplu olarak ikamet ülkesine gönderilir. Kaynak ülkesi, topladığı bilgilerin en üst seviyede şifrelenip, güvenli bir şekilde aktarılmasını sağlamalıdır. Kaynak ülkeden gönderilen bilgiler, ikamet ülkesinin vergi otoriteleri tarafından teslim alınarak şifrelenir.

\section{Tablo 1: Otomatik Bilgi Paylaşımı Süreci}

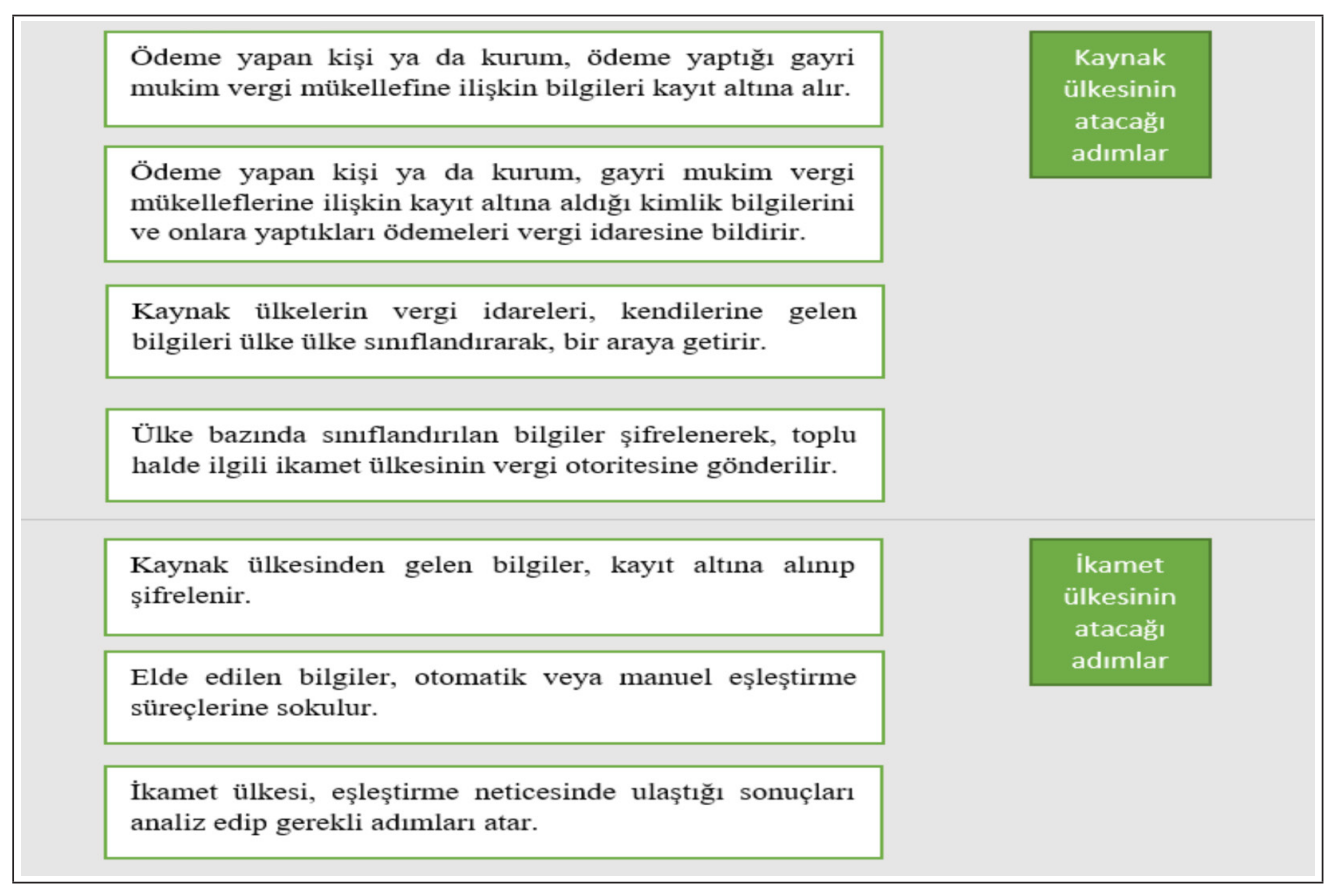

Kaynak: OECD(2012b). Automatic exchange of information: What it is, how it works, benefits, what remains to be done. Erişim Tarihi: 11.11.2019, https://www.oecd.org/ctp/ exchange-of-tax-information/automatic-exchangeofinformationreport.pdf

İkamet ülkesi, gelen bilgileri otomatik veya manuel eşleştirme sürecine tabi tutar. İlgili bilgilerin kullanımı ve eşleştirme şekli ülkeden ülkeye değişmektedir. Burada asıl önemli olan, kaynak ülkeden gelen bilgilerle yerel bilgilerin eşleştirilebilmesi ve mükellefin doğru tespit edilmesidir. Bu süreçte çoğu ülke, veri tabanında yer alan bilgilerin otomatik olarak eşleştirilmesini sağlayan, kendilerine özgü otomatik eşleştirme sistemleri geliştirmiştir. Otomatik eşleştirme sürecinde eşleşmeyen bilgiler manuel olarak eşleştirilmektedir (Bkz. Tablo 1). İkamet ülkesi, eşleştirme neticesinde ulaştığı bulguları analiz eder ve mükellefin ilgili mevzuata uymadığının tespiti durumunda gerekli adımları atar. Bazı durumlarda kaynak ülkeden ilaveten bir takım özel bilgiler de talep edilebilir (OECD, 2012b:11).

\subsubsection{Otomatik Bilgi Paylaşımında Güncel Durum}

OECD ve G20 ülkelerinin desteğiyle geliştirilen Vergi Konularında Finansal Hesap Bilgilerinin Otomatik Değişimi Standardı (Standart for Automatic Exchange of Financial Account Information for Tax Purposes, AEOI)'nın Küresel Forum tarafından kabul edilmesine 
dair bilgilere önceki bölümlerde yer verilmişti. Küresel Forum, uluslararası bilgi paylaşımına ilişkin bu yeni standardı 2014 yılında kabul etmiş olmakla beraber, bütün üyelerin derhal yeni standarda geçişini mecbur kılmamıştır. Küresel Forum, üyelerin hukuki mevzuat ve idariteknik altyapı bakımından farklı seviyelerde olabileceğini göz önünde bulundurarak, gerekli hazırlıkların yapılması için bir süre belirlemiştir. Bu kapsamda 100 vergi idaresi 2017 veya 2018 itibariyle partner ülkelerle bilgi paylaşımına başlayacağını taahhüt etmiştir.

Uluslararası vergi şeffaflı̆̆ının artırılması ve mükelleflerin vergiye uyumunun sağlanması için Otomatik Bilgi Değişimi Standardı'nın hayati bir öneme sahip olduğu düşünülmektedir. Çünkü mükelleflerin sınır ötesi faaliyetleri hakkında bilgi sahibi olamamak, ülkelerin vergi gelirlerini ciddi biçimde törpülemektedir. Küresel Forum üyelerinin, uluslararası faaliyetlerden kaynaklı vergi kaybından ne denli zarar gördükleri, daha 2017 yılında 100 idareden 86'sının otomatik bilgi paylaşımına başlamasından anlaşılabilir. 2018 yılında Küresel Forum üyeleri arasında gerçekleştirilen karşılıklı bilgi paylaşımı miktarı 4500 civarındadır (OECD, 2018a:7). Eylül 2019 itibariyle yeni standart çerçevesinde bilgi paylaşımında bulunmaya başlayan ülkelerin sayısı 93'e yüksselmiştir. Tablo 2'de uluslararası bilgi paylaşımında bulunan ülkeler ve bu ülkelerin kaç adet vergi idaresiyle bilgi paylaşımında bulunduğuna ilişkin veriler yer almaktadır.

Küresel Forum, yeni standarda geçiş hususunda gelişmekte olan ülkeler ile gelişmiş ülkeleri birbirinden ayırmakta ve gelişmekte olan ülkelere daha uzun zaman tanımaktadır. Hatta yeni sisteme alışmaları için, gelişmekte olan ülkeleri pilot projelere davet etmektedir. Pilot projelerde, gelişmekte olan ülkeler gelişmiş ülkeler ile eşleştirilmekte ve yeni standarda uyumları kolaylaştırılmaya çalışılmaktadır. Bu çerçevede Kolombiya ile İspanya ve Pakistan ile İngiltere arasındaki pilot projeler, Kolombiya'nın 2017'de, Pakistan'ın ise 2018'de Otomatik Bilgi Paylaşımı Standardına geçmesiyle başarıya ulaşmıştır. Hali hazırda uygulama aşamasında olan beş adet pilot proje kapsamındaki eşleştirmeler şu şekildedir (OECD, 2018a:4):

- Arnavutluk - İtalya

- Gürcistan - Almanya

- Gana-İniltere

- Fas - Fransa

- Filipinler - Avustralya 
Tablo 2: Bilgi Paylaşımında Bulunan İdareler ve Paylaşımda Bulundukları İdare Sayısı ${ }^{5}$

\begin{tabular}{|c|c|c|c|c|c|}
\hline $\begin{array}{c}\text { Paylaşımında } \\
\text { Bulunan Ülkeler }\end{array}$ & $\begin{array}{c}\text { Partner } \\
\text { Sayısı }\end{array}$ & $\begin{array}{c}\text { Paylaşımında } \\
\text { Bulunan Ülkeler }\end{array}$ & $\begin{array}{l}\text { Partner } \\
\text { Sayisi }\end{array}$ & $\begin{array}{c}\text { Paylaşımında Bulunan } \\
\text { Ülkeler }\end{array}$ & $\begin{array}{c}\text { Partner } \\
\text { Sayısı }\end{array}$ \\
\hline Andorra & 39 & Fransa & 62 & Hollanda & 61 \\
\hline Anguilla & 4 & Almanya & 63 & Yeni Zelanda & 55 \\
\hline Antigua ve Barbuda & 43 & Cebelitarık & 51 & Norveç & 64 \\
\hline Arjantin & 56 & Yunanistan & 62 & Pakistan & 40 \\
\hline Aruba & 50 & Grönland & 57 & Panama & 32 \\
\hline Avustralya & 57 & Grenada & 41 & Polonya & 66 \\
\hline Avusturya & 46 & Guernsey & 61 & Portekiz & 66 \\
\hline Azerbaycan & 33 & Hong Kong (Çin) & 36 & Katar & 9 \\
\hline Bahamalar & 36 & Macaristan & 57 & Romanya & 59 \\
\hline Bahreyn & 38 & İzlanda & 59 & Rusya & 14 \\
\hline Barbados & 57 & Hindistan & 60 & Saint Kitts ve Nevis & 25 \\
\hline Belçika & 66 & Endonezya & 59 & Saint Lucia & 40 \\
\hline Belize & 47 & İrlanda & 66 & $\begin{array}{l}\text { Saint Vincent ve } \\
\text { Grenadinler }\end{array}$ & 65 \\
\hline Bermuda & 52 & Man Adası & 57 & Samoa & 45 \\
\hline Brezilya & 56 & İsrail* & 41 & San Marino & 57 \\
\hline British Virgin Adaları & 50 & İtalya & 64 & Suudi Arabistan & 56 \\
\hline Bulgaristan & 60 & Japonya & 55 & Seyşeller & 55 \\
\hline Kanada & 56 & Jersey & 58 & Singapur & 50 \\
\hline Cayman Adaları & 57 & Kore (Güney) & 59 & Slovakya & 62 \\
\hline Şili & 48 & Letonya & 56 & Slovenya & 64 \\
\hline Çin & 52 & Lübnan & 27 & Güney Afrika & 57 \\
\hline Kolombiya & 60 & Liechtenstein & 50 & İspanya & 66 \\
\hline Cook Adaları & 45 & Litvanya & 63 & İsveç & 61 \\
\hline Kosta Rica & 49 & Lüksemburg & 66 & İsviçre & 36 \\
\hline Hirvatistan & 60 & Macau (Çin) & 35 & Türkiye & 1 \\
\hline Curaçao & 57 & Malezya & 42 & Turks ve Caicos Adaları & 44 \\
\hline Kibris & 59 & Malta & 61 & Birleşik Arap Emirlikleri & 43 \\
\hline Çekya & 60 & Marshall Adaları & 1 & Birleşik Krallık & 62 \\
\hline Danimarka & 66 & Mauritius & 58 & Uruguay & 59 \\
\hline Estonya & 62 & Meksika & 60 & & \\
\hline Faroe Adaları & 57 & Monaco & 34 & & \\
\hline Finlandiya & 66 & Nauru & 48 & & \\
\hline
\end{tabular}

Kaynak: OECD (2019), Erişim Tarihi: 21.09.2019, http://www.oecd.org/tax/automatic-exchange/commitment-andmonitoring-process/AEOI-Exchanges-2018.pdf.

5 Not: Tabloda yer alan rakamlar Eylül 2019’a kadar olan bilgi paylaşımlarına ilişkindir. 
Azerbaycan ve Pakistan, Küresel Forum tarafından kesin bir tarih dayatılmamasına rağmen 2018 yılında kendi istekleriyle yeni standarda geçmiş; Azerbaycan 33, Pakistan ise 40 partner ülkeyle bilgi paylaşımına başlamıştır. Bu iki ülkenin yeni standarda geçişteki istekliliği, otomatik bilgi paylaşımının sadece gelişmiş ülkelerin değil, gelişmekte olan ülkelerin de lehine olduğunu göstermektedir. Nitekim birçok gelişmekte olan ülke yeni standarda geçiş için hazırlık aşamasındadır. Örneğin Gana, 2018 de geçmeyi planlamaktayken, gerekli hazırlıkları tamamlayamadığı için tarihi ertelemiş ve ilk otomatik bilgi paylaşımını 2019 yılı içinde gerçekleştireceğini ilan etmiştir. ${ }^{6}$ Yine gelişmekte olan ülkelerden Nijerya 2019'da, Arnavutluk, Peru ve Maldivler ise 2020 yılında otomatik bilgi paylaşımında bulunmayı planlamaktadır (OECD 2018a:4). Küresel Forum, gelişmekte olan ülkelerin yeni standarda katılımına bilhassa önem vermektedir. Bu sebeple, Küresel Forum tarafından Gelişmekte Olan Ülkelerin Otomatik Bilgi Paylaşımı Standardına Katılımı İcin Eylem Planı (The Global Forum's Plan of Action for Developing Countries Participation in AEOI) adıyla bir çalışma yapılmış ve bu ülkelerin yeni standarttan faydalanabilmeleri için yapılan ve yapılacak olan faaliyetler hakkında bilgi verilmiştir.

Otomatik Bilgi Paylaşımı Standardına geçmek isteyen ülkelerin atması gereken bir takım hukuki ve teknik adımlar bulunmaktadır. İlk olarak, finansal kurumların paylaşıma konu bilgileri toplayıp raporlamasını sağlayacak, iç hukuki düzenlemelerin yapılması gerekmektedir. İkinci olarak, otomatik bilgi paylaşımı ağının genişletilebilmesi için diğer partner ülkelerle gerekli uluslararası anlaşmaların yapılması icap etmektedir. Üçüncü olarak, OECD’nin Ortak İletim Sistemi'ne (Common Transmission System, CTS) bağlanabilmek için gerekli teknik hazırlıkların tamamlanması gerekmektedir (OECD, 2018a:1) Küresel Forum, gelişmekte olan ülkelerin yeni standarda geçiş için gerekli düzenlemeleri yapmasının gelişmiş ülkelere göre daha fazla vakit alacağını düşündüğünden, gelişmekte olan ülkelere esnek davranmaktadır. Nitekim Otomatik Bilgi Paylaşımı Standardına geçmeyi arzuladıkları halde, gelişmekte olan bazı ülkeler teknik nedenlerle, bazıları ise hukuki nedenlerle katılım tarihini ertelemiştir.

OECD’nin 2018 Yılı Otomatik Bilgi Paylaşımı Uygulama Raporu'nda teknik nedenlerle henüz bilgi paylaşımında bulunmayan ülkeler kategorisinde bulunan Saint Vincent ve Grenadinler, Marshall Adaları ve Rusya gerekli düzenlemeleri yaparak bilgi paylaşımına başlamışlardır. Eylül 2019 itibariyle teknik sebepleri gerekçe göstererek bilgi paylaşımına başlamamış tek ülke Montserrat'tır. Yine aynı raporda, hukuki altyapı yetersizliği nedeniyle otomatik bilgi paylaşımına başlamamış ülkeler kategorisinde bulunan Türkiye, Katar, İsrail, Antigua ve Barbuda gerekli hazırlıkları tamamlayarak otomatik bilgi paylaşımına başlamışlardır. Eylül 2019 itibariyle, hukuki altyapı hazırlığı gerekçesiyle henüz bilgi paylaşımına başlamamış ülkeler kategorisinde Bruney, Dominik, Niue, Saint Martin, Trinidad ve Tobago ile Vanuatu bulunmaktadır (OECD, 2018b).

Tablo 2'de dikkat çeken bir husus da Amerika Birleşik Devletleri'nin yeni standart çerçevesinde bilgi paylaşımında bulunan ülkeler arasında yer almayışıdır. Bunun sebebi ABD’nin, vergi konularında bilgi paylaşımını 2010 yılında çıkardığı Yabancı Hesaplar Vergi Uyum Yasası (Foreign Account Tax Compliance Act, FATCA) ile düzenlemesi ve OECD standardına dâhil olmamasıdır. ABD, FATCA ile ülke dışında faaliyet gösteren ABD vatandaşlarına ilişkin finansal bilgilere ulaşmayı hedeflemektedir. Buna göre yabancı ülke finans

6 Not: Gana, Eylül 2019 itibariyle, Otomatik Bilgi Değişimi Standardına henüz geçebilmiş değildir. 
kuruluşlarının, ABD vatandaşlarına ait sahip oldukları finansal bilgileri ABD'ye bildirmeleri gerekmektedir. FATCA'ya katılım görünüşte isteğe bağlı olmakla beraber, anlaşmaya katılmayan finans kuruluşlarına yapılan ABD kaynaklı ödemelere getirilen \%30 oranında stopaj ile zorunlu bir niteliğe bürünmektedir (Brodzka, 2013:9). Zira bir finans kuruluşunun ABD kaynaklı alacaklarının \%30’unu peşinen kaybetmeyi göze alması çok zordur.

FATCA kapsamında, ABD vatandaşlarına ait bilgilerin doğrudan doğruya yabancı finans kuruluşları tarafından IRS'e (Amerikan Dâhili Gelir İdaresi-Internal Revenue Service) gönderilmesi, bilgilerin güvenliğinin tehlikeye atıldığı ve diğer devletlerin anayasal haklarının çiğnendiği şeklinde eleştirilere neden olmuştur (Parillo, 2013:1031). Ayrıca ABD vergi mükelleflerine ait bilgilerin yabancı finans kuruluşları tarafından IRS'e gönderilmesi, karşılıklı değil tek taraflı bilgi paylaşımının söz konusu olması bakımından da tepki görmüştür. $\mathrm{Bu}$ tür eleştirileri gidermek adına Hükümetlerarası Anlaşma Modelleri (Intergovernmental Agreements, IGAs) geliştirilmiştir. Bu çerçevede Model 1 ve Model 2 olmak üzere iki anlaşma türü mevcuttur. Model 1'de hem karşılıklı (reciprocal) hem de tek taraflı (non-reciprocal) bilgi paylaşımı yapılabilmektedir. Model 2'de ise yalnızca partner ülkeden ABD'ye tek taraflı bilgi gönderimi bulunmaktadır. Model 1'de yabancı ülkelerin finans kuruluşları, ABD mükelleflerine ait finansal bilgileri kendi mukimi oldukları devletlere iletmekte, söz konusu bilgiler bu devletler tarafından ABD'ye gönderilmektedir. Model 2'de ise ABD vergi mükelleflerine ait finansal bilgiler, yabancı Finans kuruluşları tarafından doğrudan IRS'e bildirilmektedir. Bu güne kadar 99'u Model 1'e, 14'ü ise Model 2'ye dayanmak üzere toplam 113 ülke FATCA anlaşmasını imzalamıştır (U.S Department of the Treasury).

OECD’nin 2014 yılında, Finansal Hesap Bilgilerinin Otomatik Paylaşımı Standardı ile Ortak Raporlama Standardı 'nı kabul etmesinden çok daha önce, 2010 yılında ABD tarafından FATCA Anlaşması uygulamaya koyulmuştur. Hatta FATCA Anlaşması, OECD ve G20 ülkelerinin otomatik bilgi paylaşımı konusundaki çalışmalarına hız kazandırmış ve FATCA'da yer alan Model 1 Anlaşması, Ortak Raporlama Standardı'nın geliştirilmesinde şablon olarak kullanılmıştır (Gadzo \& Klemencic, 2017:209). Dolayısıyla ABD’nin vergi konularında otomatik bilgi paylaşımı faaliyetleri, OECD Ortak Raporlama Standardı 'nın dışında yer almaktadir.

\section{Vergi Konularında Uluslararası Bilgi Paylaşımı ve Türkiye}

Vergi konularında, idareler arasında karşılıklı bilgi paylaşımında bulunulabilmesi için bazı hukuki ve teknik şartların yerine getirilmesi gerekmektedir. Teknik şartlar, paylaşıma konu olacak bilgilerin toplanması, raporlanması, mahremiyetinin korunması ve gönderilmesine ilişkin prosedürler ve teknolojik altyapı yeterliliğini ifade etmektedir. Hukuki şartlar ise paylaşıma konu olacak bilgilerin elde edilmesi ve gönderilmesi ile ilgili her türlü kanuni düzenlemeyi kapsamaktadır. Hatta paylaşılacak bilgilerle ilgili gerekli teknik şartların yerine getirilebilmesi için de hukuki düzenlemelere ihtiyaç vardır. Zira mükellefe ait bilgilerin toplanması, raporlanması, bilgilerin gizliliğin sağlanması ve gönderilmesi ancak hukuka dayanılarak gerçekleştirilebilir. Bilgi paylaşımı hususunda gerekli hukuki şartların, biri ulusal diğeri uluslararası, iki boyutu bulunmaktadır. Bunlardan ilki, söz konusu bilgilerin ülke dahilinde toplanıp raporlanmasına imkân veren iç hukuki düzenlemeler iken, diğeri toplanan bilgilerin idareler arasında mütekabiliyet esası çerçevesinde paylaşılmasına imkân tanıyan milletlerarası sözleşmelerdir. 


\section{1. İç Hukuk Sistemi Çerçevesinde Yer Alan Düzenlemeler}

Türk Hukuk Sistem'inde vergi konularında bilgi paylaşımına ilişkin iç hukuki düzenlemeler 213 Nolu Vergi Usul Kanunu'nun 148, 152 ve 152/A maddelerinde yer almaktadır. VUK madde 148' de “Kamu idare ve müesseseleri, mükellefler veya mükelleflerle muamelede bulunan diğer gerçek ve tüzel kişiler, Hazine ve Maliye Bakanlı ğı'nın veya vergi incelemesi yapmaya yetkili olanlarm isteyecekleri bilgileri vermeye mecburdurlar. Bilgiler yazi veya sözle istenilir. Sözle istenen bilgilerin verilmemesi durumunda keyfiyet yazı ile te'kit edilerek cevap vermeleri için kendilerine münasip bir mühlet tayin olunur" hükmüne yer verilerek bilgi toplamanın hukuki dayanağı oluşturulmuştur. VUK madde 158 'de ise toplanan bilgilerin istihbarat arşivlerinde gizli olarak saklanacağı ve bu arşivlerden kimlerin faydalanacağının Hazine ve Maliye Bakanlığı'nca tayin olunacağı hüküm altına alınmıştır. Ancak 1961 yılında yürürlüğe giren Vergi Usul Kanunu'nda, 148'inci maddeye dayanılarak toplanan bilgilerin uluslararası paylaşımına dair, uzun süre bir hüküm yer almamıştır. Bu eksikliği gidermek adına

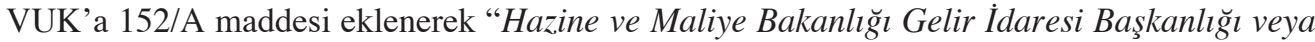
vergi incelemesi yapmaya yetkili olanlar, usulüne uygun olarak yürürlüğe girmiş uluslararası anlaşmalarda yer alan bilgi değ işimi hükümleri çerçevesinde, Hazine ve Maliye Bakanlı̆̆ı'nca tespit edilecek usullere göre bu Kanunu'n l'inci maddesinde belirlenen şümulle sinırlı olmaksızın bilgi toplayabilir" hükmüne yerilmiştir. VUK'un 1'inci maddesinde bu kanun hükümlerinin, gümrük ve tekel vergileri hariç, genel bütçeye, il özel idarelerine ve belediyelere ait vergi, resim ve harçlar ile bunlara ait zamlar hakkında uygulanacağı belirtilmektedir. Eklenen 152/A maddesinde bilhassa “bu Kanun'un 1'inci maddesinde belirlenen şümulle sınırlı olmaksızın" ibaresine yer verilmesiyle uluslararası anlaşmalar çerçevesinde toplanacak bilgilerin kapsamı VUK'un çizdiği sınırların ötesine taşınmıştır.

Türkiye'de vergi konularında uluslararası bilgi paylaşımına yönelik bir iç hukuk düzenlemesi de 2006 yılında yürürlüğe giren 5549 sayılı Suç Gelirlerinin Aklanmasının Önlenmesi Hakkında Kanun'dur. Ancak bu kanun çerçevesinde vergiyle ilgili bilgilerin yabancı ülkelerdeki muadil kurumlarla paylaşımı ancak VUK madde 359'da belirtilen kaçakçılık fiillerinin varlığı halinde mümkün olmaktadır (Yavaşlar, 2015:29). Bu bakımdan, 5549 sayılı Kanun'un, vergi konularında uluslararası bilgi paylaşımını dolaylı olarak kapsamına aldığı görülmektedir.

\subsection{Uluslararası Hukuk Çerçevesinde Yer Alan Düzenlemeler}

Vergi idarelerinin, vergilendirmeye ilişkin hususlarda karşılıklı bilgi paylaşımında bulunmaları devletler arası bir mesele olduğundan, uluslararası hukuk kapsamında gerçekleştirilmektedir. Uluslararası hukuk ise bir tür sözleşme hukuku olduğundan, vergi konularında bilgi paylaşımı uluslararası sözleşmelere dayanmaktadır. Türkiye Cumhuriyeti Anayasası'nın 90'ınc1 maddesinde “'usulüne uygun olarak yürürlüğe girmiş uluslararası anlaşmalar kanun hükmünde olup, bunlar hakkında Anayasa'ya aykırılık iddiası ile Anayasa Mahkemesi'ne iptal davası açılamaz" hükmüne yer verilmiştir. Aynı maddede "temel hak ve özgürlükler bakımından milletler arası anlaşmalarla kanunların farklı hükümler içermesi durumunda, milletler arası anlaşma hükümleri esas alınır" hükmü de bulunmaktadır. $\mathrm{Bu}$ bakımdan milletler arası anlaşmaların birçok konuda milli kanunlardan üstün olduğu söylenebilir.Zira yürürlükte olan bir kanun hakkında Anayasa' ya aykırılık iddiasıyla iptal davası açılabilmekteyken, uluslararası anlaşmalar hakkında böyle bir iptal davası açılamamaktadır. 
Ülkelerin vergi konularında karşılıklı bilgi paylaşımında bulunabilmeleri için çeşitli yollar mevcuttur. Esasında bu yolların tamamı uluslararası bir sözleşmeye dayanmakta sadece kapsam ve yöntem olarak birbirinden farklılık arz etmektedir. Bu yöntemlerden ilki ve en yaygın olarak kullanılanı, bilgi paylaşımının çifte vergilendirmeyi önleme anlaşmaları altında gerçekleştirilmesidir. Bunun yanında, iki veya daha fazla ülke, imzaladıkları iki veya çok taraflı anlaşmalarla bilgi paylaşımında bulunabilmektedir.

Tablo 3: Türkiye'nin Çifte Vergilendirmeyi Önleme Anlaşmaları Çerçevesinde Karşılıklı Bilgi Paylaşımında Bulunduğu Ülkeler

\begin{tabular}{|c|c|c|}
\hline Avusturya & Polonya & Estonya \\
\hline Norveç & Türkmenistan & İran \\
\hline Güney Kore & Azerbaycan & Fas \\
\hline Ürdün & Bulgaristan & Lübnan \\
\hline Tunus & Özbekistan & Güney Afrika C. \\
\hline Romanya & A.B.D. & Portekiz \\
\hline Hollanda & Beyaz Rusya & Sırbistan-Karadağ \\
\hline Pakistan & Ukrayna & Etiyopya \\
\hline İngiltere & İsrail & Bahreyn \\
\hline Finlandiya & Slovakya & Katar \\
\hline K.K.T.C. & Kuveyt & Bosna-Hersek \\
\hline Fransa & Rusya & Suudi Arabistan \\
\hline Almanya & Endonezya & Gürcistan \\
\hline İsveç & Litvanya & Umman \\
\hline Belçika & Hirvatistan & Yemen \\
\hline Danimarka & Moldova & İrlanda \\
\hline İtalya & Singapur & Yeni Zelanda \\
\hline Japonya & Kirgızistan & Kanada \\
\hline B.A.E. & Tacikistan & İsviçre \\
\hline Macaristan & Çek Cumhuriyeti & Brezilya \\
\hline Kazakistan & İspanya & Avustralya \\
\hline Makedonya & Bangladeş & Malta \\
\hline Arnavutluk & Letonya & Meksika \\
\hline Cezayir & Slovenya & Kosova \\
\hline Moğolistan & Yunanistan & Filipinler \\
\hline Hindistan & Suriye & Vietnam \\
\hline Malezya & Tayland & Gambiya \\
\hline Misır & Sudan & \\
\hline Çin Halk Cum. & Lüksemburg & \\
\hline
\end{tabular}

Kaynak: GİB (2019). Erişim Tarihi: 12.12.2019, https://www.gib.gov.tr/uluslararasi_mevzuat. 
Günümüzde yaygın olarak kullanılan bir diğer yöntem ise bilgi paylaşımının uluslararası bir organizasyon çatısı altında gerçekleştirilmesidir. Türkiye, vergi konularında bilgi paylaşımı için bu üç yöntemi de kullanmaktadır. Tablo 3 'te Türkiye'nin çifte vergilendirmeyi önleme anlaşmalarına konulan hükümlerle karşılıklı bilgi paylaşımında bulunduğu ülkelerin listesi yer almaktadır. Eylül 2019 itibariyle Türkiye'nin sadece çifte vergilendirmeyi önleme anlaşmaları kapsamında karşılıklı bilgi paylaştığı 85 ülke bulunmaktadır.

OECD, uluslararası şeffaflığın artırılarak vergi kayıp ve kaçağının önlenmesi için idareler arası bilgi paylaşımına büyük önem vermektedir. OECD, üyesi olan ülkelerin yanında üye olmayan devletlerin de sağlıklı bir şekilde bilgi paylaşımında bulunabilmelerini kolaylaştırmak adına çeşitli araçlar oluşturmuştur. Bu araçlardan OECD Model Vergi Anlaşması ve CoE/OECD Vergi Konularında Karşılıklı İdari Yardımlaşma Anlaşması daha çok OECD üyelerine hitap etmektedir. OECD, aralarında daha önce herhangi bir vergi anlaşması bulunmayan ülkelerin de bilgi paylaşımında bulunmalarını teşvik etmek ve onlara yol göstermek adına Vergiye İlişkin Bilgilerinin Paylaşımı Anlaşması (Tax Information Exchange Agreement, TIEA) Model'ini hazırlamıştır. Türkiye'nin TIEA Modeli kapsamında bilgi paylaşımında bulunduğu partner ülkeler Tablo 4'te yer almaktadır.

Tablo 4: Türkiye'nin TIEA Modeli Kapsamında Bilgi Paylaşımında Bulunduğu Ülkeler

\begin{tabular}{lccc}
\hline Taraf Ülke & Imza Tarihi & Yürürlük Tarihi & Anlaşmanın Türü \\
\hline Jersey & 24.11 .2010 & 11.09 .2013 & Talep Üzerine Bilgi Paylaşımı \\
\hline Bermuda & 23.01 .2012 & 18.09 .2013 & Talep Üzerine Bilgi Paylaşımı \\
\hline Guernsey & 13.03 .2012 & 06.10 .2017 & Talep Üzerine Bilgi Paylaşımı \\
\hline Man Adası & 21.09 .2012 & 07.10 .2017 & Talep Üzerine Bilgi Paylaşımı \\
\hline Cebelitarık & 04.12 .2012 & 15.02 .2018 & Talep Üzerine Bilgi Paylaşımı \\
\hline
\end{tabular}

Kaynak: GIBB (2019), Erişim Tarihi: 26.09.2019, https://www.gib.gov.tr/uluslararasi_mevzuat.

Tablo 4'e bakıldığında Türkiye'nin TIEA Modeli kapsamında karşılıklı bilgi paylaşımında bulunduğu beş ülkenin tamamının vergi cenneti olarak nitelenen ülkeler olduğu görülmekte ve anlaşma türünün talep üzerine bilgi paylaşımı şeklinde olduğu dikkat çekmektedir. Bunun en önemli sebebi söz konusu anlaşmaların 2015 yılından önce imzalanmış olmasıdır. Zira 2015 yılına kadar TIEA Modeli kapsamında sadece talep üzerine bilgi paylaşımına imkân tanınmaktayken, 2015'te yapılan bir düzenleme ile otomatik bilgi paylaşımı ile spontane bilgi paylaşımı türleri de model kapsamına alınmıştır.

Türkiye, 1988 yılında Avrupa Komisyonu ve OECD tarafından kabul edilen ve 2010 yılında tadil edilerek etkinliği artırılan Vergi Konularında Karşılıklı İdari Yardımlaşma Sözleşmesi'ni 3 Kasım 2011 Tarihi’nde imzalamıştır. Fakat bu anlaşma ancak 2017 yılında onaylanarak yürürlüğe girmiştir. Günümüzde OECD çatısı altında gerçekleştirilen bilgi paylaşımlarının temel hukuki dayanağı bu anlaşmadır. Zira OECD Model Vergi Sözleşmesi'nin bilgi paylaşımına ilişkin 26'ncı maddesinde bilgi paylaşım türlerine sadece değinilmekle iktifa edilmiş ve herhangi bir tanıma yer verilmemiştir. Halbuki Karşılıklı İdari Yardımlaşma Sözleşmesi'nin 5, 6 ve 7 maddeleri sırasıyla, talep üzerine bilgi paylaşımı, otomatik bilgi paylaşımı ve spontane bilgi paylaşımını düzenlemektedir. 
2014 yılında OECD'nin Vergi Konularında Finansal Hesap Bilgilerinin Otomatik Değişimi Paylaşımı Standardını kabul etmesiyle Türkiye'de bu standardı uygulamak üzere hazırlıklara başlamıştır. OECD, katılım sürecinde gelişmiş ülkeler gelişmekte olan ülkeler arasındaki dengeyi sağlamak adına yeni standarda geçiş için bir taahhüt süreci oluşturmuş ve bu aşamada gelişmekte olan ülkelere esneklik tanımıştır. Küresel Forum'un 100 üyesinin bazıları 2017'de, bazıları ise 2018 de otomatik bilgi paylaşımına başlayacağını taahhüt etmiştir. Bu süreçte Türkiye, 2018 yılında otomatik bilgi paylaşımına başlayacağını taahhüt eden ülkeler arasında olup bu taahhüdünü yerine getirmiştir. Fakat Tablo 2'ye bakıldığgnda Türkiye'nin Eylül 2019 itibariyle yeni standart kapsamında henüz sadece tek bir partner ülkeyle bilgi paylaşımında bulunduğu görülmektedir. Halbuki çoğu ülkenin, yeni standart kapsamında bilgi paylaştığı partnerlerin sayısı çift haneli rakamlardadır.

Türkiye ayrıca FATCA Anlaşmasını imzalamış olup, ABD ile Model 1 kapsamında karşılıklı bilgi paylaşımında bulunmaktadır. Esasında Türkiye'nin imzaladı̆̆ı FATCA Anlaşması daha önce ABD ile Türkiye arasında imzalanan çifte vergilendirmeyi önleme anlaşmasının bilgi paylaşımı ile ilgili maddesine dayanmaktadır. Ancak çifte vergilendirmeyi önleme anlaşmalarında talep üzerine, otomatik ve spontane bilgi paylaşımı türleri mevcut iken FATCA Anlaşmasıyla yalnız otomatik bilgi paylaşımında bulunulabilmektedir.

\section{Sonuç}

Küreselleşmenin etkisiyle üretim faktörlerinin mobilitesinin artması iktisadi sistemde köklü değişiklikler meydana getirmiştir. Küreselleşme sürecinde teknolojinin, 20. Yüzyıl öncesiyle kıyaslanamayacak şekilde ilerlemesi ulaşım ve nakliye maliyetlerini düşürmüş, bireylere ve firmalara yüksek hareket kabiliyeti kazandırmıştır. Bu hareket kabiliyeti sınır ötesi faaliyetleri kolaylaştırmış ve dünya ticaret hacmini artırmıştır. Sınır ötesi faaliyetlerin kolaylaşması bireylere ve firmalara yani vergi mükelleflerine fevkalade imkanlar sunarken, vergi idareleri açısından olumsuz durumlar ortaya çıkarmıştır.

Vergi mükellefleri sınır ötesine geçip serbest hareket imkanına kavuşurken, bunları takip edip yükümlendirmekle görevli vergi idarelerinin yetkileri ülke sınırları içine hapsolmaktadır. Sınır ötesi işlemlerin tespit ve takibinin zorlaşması vergi şeffaflığını ortadan kaldırdığından sağlıklı bir vergilendirme sürecini engellemektedir. Bu durum ülkelerin vergi kapasitelerini, dolayısıyla gerçek vergi matrahlarını olumsuz yönde etkilemekte ve aynı zamanda uluslararası kayıt dışılığı da artırmaktadır.

Gelinen noktada, vergi şeffaflığını artırmak için vergi idareleri arasındaki koordinasyon ve işbirliğini geliştirmekten başka yol yoktur. Vergi idarelerinin, sınır aşırı faaliyetleri olan vergi mükellefleri hakkında bilgi sahibi olabilmesi, dolayısıyla vergi-şeffaf bir çevre oluşturulabilmesi için gerek anaakım devletlerin gerekse çok uluslu organizasyonların en önem verdikleri konu uluslararası bilgi paylaşımıdır. Vergi konularında uluslararası bilgi paylaşımı ülkeler arasında imzalanan anlaşmalarla gerçekleştirilmektedir. Uluslararası organizasyonlar, ülkeler arasındaki koordinasyonu sağlamak ve bilgi paylaşımını kolaylaştırmak için çeşitli hukuki ve teknik araçlar üretmektedir. Bu bakımdan en faal olan ve en kapsamlı çalışmalar yapan uluslararası organizasyon OECD'dir. OECD’nin vergi konularında uluslararası işbirliğini artırmak için kuruluşundan bu yana çok sayıda çalışması mevcuttur. Bu çalışmaların nerdeyse tamamının, bilgi paylaşımıyla bir şekilde bağlantısı bulunmaktadır. Ancak OECD kaynaklı araçlar 
içerisinde uluslararası bilgi paylaşımında doğrudan hukuki dayanak teşkil eden düzenlemeler OECD Model Vergi Anlaşması, OECD Vergi Konularında Bilgi Değişim Anlaşması Modeli (Model TIEA) ve CoE/OECD Vergi Konularında Karşılıklı İdari Yardımlaşma Anlaşması'dır.

OECD, vergi konularında bilgi paylaşımının her türüyle ilgili çalışmalar yapmakla beraber 2014 yılında Finansal Hesap Bilgilerinin Otomatik Değişimi Standardı'nın kabul edilmesiyle yeni bir sisteme geçilmiş ve otomatik bilgi paylaşımı diğer bilgi paylaşımı türlerine göre daha çok tercih edilmeye başlamıştır. Ancak OECD'nin otomatik bilgi paylaşımına önem vermesi, talep üzerine ve spontane bilgi paylaşımı türlerini göz ardı ettiği anlamına gelmemektedir. OECD’nin amacı bu bilgi paylaşım türlerinden birini diğerine üstün kılmak veya bilgi paylaşımın mutlaka OECD çatısı altında yapılmasını sağlamak değil her hal ve şartta bilgi paylaşımını teşvik etmektir. Nitekim OECD, bilgi paylaşımını kolaylaştırmak ve paylaşıma konu olacak bilgilerin kapsamını genişletmek için hukuki araçları sürekli güncellemekte ve zaman zaman da yeni araçlar geliştirmektedir. Ancak mükelleflerin idareler arası paylaşıma konu olacak bilgilerinin kapsamının sürekli genişletilmesi, hem zaman ve usul ekonomisini artırmakta hem de mükellef haklarına aykırı olduğu iddiasıyla eleştirilmektedir.

OECD’nin 2014 y1lında G20 ülkelerinin istek ve desteğiyle Ortak Raporlama Standardı'nı geliştirmesi vergi konularında uluslararası bilgi paylaşımı alanında bir milat olarak görülebilir. Ortak Raporlama Standardı ile gelişmiş ülkelerin yanında gelişmekte olan ülkelerin otomatik bilgi paylaşımına katılımı da artmıştır. OECD Ortak Raporlama Standardı'nın yaygınlaştırılmasında gelişmekte olan ülkelere bilhassa önem vermekte ve bu ülkelere her türlü hukuki ve teknik yardımı sağlamaktadır. Ortak Raporlama Standardı'nın kabul edilmesinden itibaren sadece gelişmiş ülkelerin değil, vergi cenneti olarak nitelendirilen ve geçmişte OECD'nin kara listesinde bulunan ülkelerin de otomatik bilgi paylaşımına başladığ 1 görülmektedir.

Türkiye'de vergi konularında uluslararası bilgi paylaşımı hususundaki gelişmeler OECD'nin bu konudaki çalışmaları ile paralel olarak gelişmiştir. Türkiye diğer ülkelerle ilk olarak OECD Model Vergi Sözleşmesi'nin 26'ncı maddesine dayanarak, çifte vergilendirmeyi önleme anlaşmaları çerçevesinde bilgi paylaşımında bulunmaya başlamıştır. Bunun yanında Türkiye'nin, TIEA Modeli kapsamında karşılıklı bilgi paylaştı̆̆ 1 ülkeler de bulunmaktadır. Türkiye, OECD’nin Avrupa Komisyonu ile 1988 yılında kabul edip 2010 yılında tadil ettiği Vergi Konularında Karşılıklı İdari Yardımlaşma Anlaşması’nı 2011 yılında imzalamış ancak 2017 yılında onaylayarak yürürlüğe koymuştur. Türkiye OECD Ortak Raporlama Standardı'nı da kabul etmiş olup 2018 yılında otomatik bilgi paylaşımına başlamıştır.

OECD’nin vergi konularında bilgi paylaşımıyla ilgili çalışmaları kronolojik olarak incelendiğinde, paylaşıma tabi olacak bilgilerin kapsamının sürekli genişletildiği görülmektedir. Başlangıçta, sadece vergilendirmeyi doğrudan ilgilendiren bilgilerin paylaşılması esas iken zaman içerisinde, vergilendirmeyi dolaylı olarak ilgilendiren bilgiler de kapsama alınmıştır. Devam eden süreçte, vergilendirmeyi doğrudan veya dolaylı olarak ilgilendiren bilgilerin yanı sıra bir şekilde vergiyle alakalı olabileceği düşünülen bilgilerin paylaşılmasına da imkân tanınmıştır. İdareler arası bilgi paylaşımının kapsamının bu denli genişlemesi küresel vergi şeffaflığ ${ }_{1}$ açısından olumlu bir gelişme olmakla beraber, mükellefler hakları ve mahremiyeti bakımından ciddi mahzurlar barındırmaktadır. Ancak gerek OECD'nin gerekse kaynak ülkelerinin bu tür mahzurları çok fazla dikkate almadığı görülmektedir. Kanaatimize göre 
bu durum, vergi şeffaflığının mevcut olmadığı bir uluslararası sistemin, ülkelerin gelirlerini tehdit etmesinden kaynaklanmaktadır. Daha açık ifade etmek gerekirse anaakım devletler, mükellef hakları ile kamu gelirleri arasında tercih yapmak zorunda kaldığında kamu gelirlerini seçmektedir.

\section{Kaynakça}

Alexander, R. M. (2013). Tax transparency. Business Horizons, 56, 543-549.

Ateş, L. (2015). Vergisel bilgilerin otomatik değişimi standardı ve Türkiye. İnönü Üniversitesi Hukuk Fakültesi Dergisi, Özel Sayı, 2, 665-682.

Brodzka, A. (2013). FATCA from European Union perspective. Journal of Governance and Regulation, 2(3), 7-13.

Coates, W. H. (1924). League of Nations report on double taxation submitted to Financial Committee by Proffesors Bruins, Einaudi, Seligman, and Sir Josiah Stamp. Journal of Royal Statistical Society. 87(1), 99-102.

CoE/OECD (1988). The multilateral convention on mutul administrative assistance in tax matters Erişim Tarihi: 12.12.2019, https://read.oecd-ilibrary.org/taxation/the-multilateral-convention-onmutual-administrative-assistance-in-tax-matters_9789264115606-en\#page1

CoE/OECD (2010). Protocol amending the convention on mutual administrative assistance in tax matters . Erişim Tarihi: 10.12.2019, https://rm.coe.int/168008482b

CoinMarketCap (2019). Erişim Tarihi: 20.11.2019, https://coinmarketcap.com/

Dean, S. A. (2008). The incomplete global market for tax information. Boston College Law Review, 49(3), 605-672.

European Commission (2015). A fair and efficient corporate tax system in the European Union: 5 key areas gor action. Erişim Tarihi:15.12.2019, https://eurlex.europa.eu/resource.html?uri=cellar:5e1fd1b015b7-11e5-a342-01aa75ed71a1.0003.01/DOC_1\&format=PDF

Gadzo, S. \& Klemencic, I. (2017). Effective international information exchange as a key element of modern tax systems: Promises and pitfalls of the OECD's common reporting standart. Public Sector Economics, 41(2), 207-226.

GİB (2019), Erişim tarihi: 26.09.2019, https://www.gib.gov.tr/uluslararasi_mevzuat

Internet World Stats (2019). Erişim Tarihi: 22.03.2019, https://www.internetworldstats.com/emarketing. $\mathrm{htm}$

League of Nations (1920). Report of the international financial conference, Volume III, Brüksel.

Murphy, R. (2012). Closing the European gap, a report for group of the progressive alliance of socialists $\&$ democrats in the European Parliament. Tax Research LLP.

OECD (1963). A draft double taxation convention on income and capital. Erişim Tarihi: 10.12.2019, https://www.oecd-ilibrary.org/taxation/draft-double-taxationconvention-on-income-andcapital_9789264073241-en

OECD (1998). Harmful tax competition: An emerging global issue. Erişim Tarihi: 13.12.2019, https:// www.oecd-ilibrary.org/taxation/harmfultaxcompetition_9789264162945-en

OECD (2000a). Towards global tax co-operation: Progress in identifying and eliminating harmful tax practices. Erişim Tarihi: 11.12.1019, https://www.oecd.org/tax/transparency/abouttheglobalforum/publications/towards-global-tax-cooperation-progress.pdf

OECD (2000b). Improving access to bank information for tax purposes. Erişim Tarihi: 09.12.2019, http:// www.oecd.org/tax/exchange-of-taxinformation/2497487.pdf 
OECD (2002a). Model agreement on exchange of information in tax matters. Erişim Tarihi: 15.12.2019, https://www.oecd-ilibrary.org/taxation/implementing-the-taxtransparencystandards/ the-2002-model-agreement-on-exchange-ofinformation-ontax-matters-and-itscommentary_9789264110496-8-en

OECD (2002b). Model memorandum of understanding between the competent authorities on the automatic exchange of information for tax purposes. Erişim Tarihi: 01.12.2019, https://www. oecd.org/ctp/exchange-of-taxinformation/2662204.pdf

OECD (2005). Update to article 26 of the OECD model tax convention an its commentary. Erişim Tarihi: 13.12.2019, http://www.oecd.org/ctp/treaties/ discussiondraftreleasedon2005updatetothemodltaconvention.htm

OECD (2012a). Update to the article 26 of the OECD model tax convention and its commentary. Erişim Tarihi: 28.11.2019, https://www.oecd.org/ctp/exchangeoftax-information/120718_Article\%20 26-ENG_no\%20cover\%20(2).pdf

OECD (2012b). Automatic exchange of information: What it is, how it works, benefits, what remains to be done. Erişim Tarihi: 11.11.2019, https://www.oecd.org/ctp/ exchange-of-tax-information/ automatic-exchangeofinformation-report.pdf

OECD (2015). Model protocol for the allowing the automatic and spontaneous exchange of information under a TIEA. Erişim Tarihi: 10.12.2019, https://www.oecd.org/ctp/exchange-of-tax-information/ Model-Protocol-TIEA.pdf

OECD (2017a). Model tax convention on income and capital: Condensed version. Erişim Tarihi: 11.12.2019, https://www.oecd.org/tax/model-tax-conventionon-income-and-on-capitalcondensed-version-20745419.htm.

OECD (2017b). Standart for automatic exchange of financial account information in tax matters. Second Edition. Erişim Tarihi: 15.12.2019, https://www.oecd.org/tax/exchange-of-taxinformation/standard-forautomaticexchange-of-financial-account-information-in-tax-matterssecondedition9789264267992-en.htm

OECD (2017c). The Global Forum's plan of action for developing countries participation in AEOI. Erişim Tarihi: 11.12.2019, https://www.oecd.org/tax/transparency/plan-of-action-AEOI-anddevelopingcountries.pdf

OECD (2018a). Automatic exchange of information implementation report. Erişim Tarihi: 09.12.2019, https://www.oecd.org/tax/transparency/AEOI-Implementation-Report-2018.pdf

OECD (2018b). Exchanges that took place in 2018 under the AEOI Standard. Erişim Tarihi: 14.12.2019, http://www.oecd.org/tax/automatic-exchange/commitment-and-monitoring-process/AEOIExchanges-2018.pdf

OECD/G20 (2015a). Countering harmful tax practices more effectively, taking into account transparency and substance (Action 5): 2015 final report. Erişim Tarihi: 08.12.2019, https://www.oecd.org/ tax/countering-harmful-tax-practices-more-effectively-taking-into-account-transparency-andsubstance-action-5-2015-final-report-9789264241190-en.htm

OECD/G20 (2015b). Transfer pricing documentaiton and country-by-country reporting (Action 13): 2015 final report. Erişim Tarihi: 09.12.2019, https://www.oecd.org/tax/transfer-pricing-documentationand-country-by-countryreporting-action-13-2015-final-report-9789264241480-en.htm

Palan, R., Murphy, R. \& Chavagneux, C. (2010). Tax havens: How globalization really works. London: Cornell University Press.

Parillo, K. A. (2013). FATCA: Vulnerable to a Canadian constitutional challenge?. Tax Notes International, 1031-1036. 
Sharman, J. C. (2009). Privacy as roguery: Personal financial information in an age of transparancy. Public Administration, 87(4), 717-731.

Stewart, M. (2018). Transparency, tax, and human rights. Melbourne Legal Studies Research Paper Series. No: 774.

Tanzi, V. (2000). Globalization, technological developments, and the work of fiscal termites. IMF Working Paper, No: WP/00/81.

UN (2017). Double taxation convention between developed and developing countries. Erişim Tarihi: 13.12.2019, https://www.un-ilibrary.org/economic-andsocial-development/united-nationsmodel-double-taxation-convention-betweendeveloped-and-developing-countries-2017-update_ cc8f6035-en

UNPAN (2019). Historical setting of the united nations model convention. Erişim Tarihi:29.03.2019, http://unpan1 .un.org/intradoc/groups/public/documents/un/unpan004555.pdf

US Congress (2017). Tax cuts and jobs act. Erişim Tarihi: 13.04.2020, https://www.congress.gov/115/ plaws/pub197/PLAW-115pub197.pdf

US Department of the Treasury (2019). Erişim Tarihi: 01.10.2019, https://www.treasury.gov/resourcecenter/taxpolicy/treaties/Pages/FATCA.aspx

Yavaşlar, F. B. (2015). Türk vergi hukukunda uluslararası bilgi değişimine izin veren hukuki kaynakların tespiti ve değerlendirilmesi. Vergi Dünyası, 401, 25-37.

Zuchman, G. (2013). The missing wealth of nations: Are europe and the U.S. net debtors or net creditors. The Quartely Journal of Economics, 1321-1364. 


\section{EXTENDED SUMMARY}

The increase in the mobility of production factors, due to globalization, has brought about radical changes in the economic systems. In the globalization process, the extraordinary advancement of technology has reduced transportation costs and provide individuals and companies with high mobility. This mobility facilitated cross-border activities and increased world trade volume. While the facilitation of cross-border activities has provided great opportunities to taxpayers, it has created adverse effects for tax administrations. While taxpayers cross the border and gain the opportunity of free movement, the powers of the tax administrations that are responsible for following them are confined within the borders of the source country. Difficulty in the detection and follow-up of cross-border transactions prevents a healthy taxation process as it eliminates tax transparency. This situation adversely affects the taxation capacities of source countries and at the same time increases international informality.

One of the most important points that both national states and multinational organizations attach the global tax transparency is to increase the exchange of information in tax matters between administrations. International exchange of information in tax matters is carried out through tax treaties between countries. In other words, the legal basis of the international exchange of information is established by international conventions. According to international law, there is no obstacle for two or more counties to cooperate in tax matters with contracts they will conclude. In time, to avoid the coordination problem between countries, the legal basis of international exchange of information has started to be formed mostly by multinational organizations. However, this situation does not oblige an exchange of information convention to be carried out only under the roof of a multinational organization. Because the main purpose of such organizations is not to keep the cooperation under their responsibility but to increase it in all circumstances. The aim of this study is to reveal the importance of the international exchange of information in tax matters by examining the factors that emerged in the globalization process and threaten tax transparency. Because it is thought that the exchange of information between tax administrations has a key role in ensuring global tax transparency.

The development of the Common Reporting Standard (CRS) by the OECD in 2014, with the request and support of the G20 countries, can be seen as a milestone in the field of international exchange of information on tax issues. With CRS, not only developed countries but also developing countries started to give importance to the automatic exchange of information. OECD gives particular importance to developing countries in the acceptance of the CRS and provides them all kinds of legal and technical assistance. Since the adoption of CRS, even the countries that were considered as tax havens and were on the blacklist in the past have started to share information automatically.

When the OECD's actions on international exchange of information in tax matters are examined chronologically, it is seen that the scope of the information to be exchanged is expanded constantly. In the beginning, it has been essential to exchange information only directly related to taxation, but over time indirect information about taxes has also been included in the scope of agreements. In the ongoing process, it has been allowed to exchange information that is thought to be related to tax in some way. While such an expansion of exchange of information between tax administrations is a positive development in terms of global tax transparency, it has serious drawbacks in terms of taxpayer rights and personal privacy. However, it is seen 
that both the OECD and the source countries do not take these drawbacks into consideration. In our opinion, this problem arises from the fact that an international system that does not have tax transparency threatens the incomes of the source countries. To put it more explicitly, when states have to choose between taxpayer rights and public revenues, they choose the second. 